Article

\title{
Climate and the Decline and Fall of the Western Roman Empire: A Bibliometric View on an Interdisciplinary Approach to Answer a Most Classic Historical Question
}

\author{
Werner Marx ${ }^{1, * \mathbb{D}}$, Robin Haunschild ${ }^{1}$ and Lutz Bornmann ${ }^{2} \mathbb{D}$ \\ 1 Max Planck Institute for Solid State Research, Heisenbergstr. 1, 70569 Stuttgart, Germany; \\ r.haunschild@fkf.mpg.de \\ 2 Division for Science and Innovation Studies, Administrative Headquarters of the Max Planck Society, \\ Hofgartenstr. 8, 80539 Munich, Germany; bornmann@gv.mpg.de \\ * Correspondence: w.marx@fkf.mpg.de; Tel.: +49(0)-711-689-1285
}

Received: 10 October 2018; Accepted: 12 November 2018; Published: 15 November 2018

\begin{abstract}
This bibliometric analysis deals with research on the decline and fall of the Western Roman Empire in connection with climate change. Based on the Web of Science (WoS) database, we applied a combination of three different search queries for retrieving the relevant literature: (1) on the decline and fall of the Roman Empire in general, (2) more specifically on the downfall in connection with a changing climate, and (3) on paleoclimatic research in combination with the time period of the Roman Empire and Late Antiquity. Additionally, we considered all references cited by an ensemble of selected key papers and all citing papers of these key papers, whereby we retrieved additional publications (in particular, books and book chapters). We merged the literature retrieved, receiving a final publication set of 85 publications. We analyzed this publication set by applying a toolset of bibliometric methods and visualization programs. A co-authorship map of all authors, a keyword map for a rough content analysis, and a citation network based on the publication set of 85 papers are presented. We also considered news mentions in this study to identify papers with impacts beyond science. According to the literature retrieved, a multitude of paleoclimatic data from various geographical sites for the time of late antiquity indicate a climatic shift away from the stability of previous centuries. Recently, some scholars have argued that drought in Central Asia and the onset of a cooler climate in North-West Eurasia may have put Germanic tribes, Goths, and Huns on the move into the Roman Empire, provoking the Migration Period and eventually leading to the downfall of the Western Roman Empire. However, climate is only one variable at play; a combination of many factors interacting with each other is a possible explanation for the pattern of long-lasting decline and final collapse. Currently, the number of records from different locations, the toolbox of suitable analytic methods, and the precision of dating are evolving rapidly, contributing to an answer for one of the most classic of all historical questions. However, these studies still lack the inevitable collaboration of the major disciplines involved: archeology, history, and climatology. The articles of the publication set analyzed mainly result from research in the geosciences.
\end{abstract}

Keywords: Roman Empire; climate change; citation analysis

\section{Introduction}

At its maximum territorial extent by the time of Trajan's death (AD 117), the Roman Empire controlled a region including Britain, Western and Southern Continental Europe, North Africa, and the Middle East, covering about 5 million square kilometers and around $20 \%$ of the world's population [1]. 
The city of Rome had about one million inhabitants and was the origin of a road network of about 80,000 kilometers, which connected the capital city with all provinces and Roman centers outside Italy. The Roman Republican and Imperial periods together was the largest and most long-lasting empire in Western Eurasia of all time. The reason for the decline and fall of the Roman Empire is one of the most classic historical questions that has been discussed among scholars for a long time. Historians have argued that Western Rome fell because of countless societal and human factors. According to Alexander Demandt [2,3], more than 200 different causes for the end of Rome have been proposed, but until now no convincing answer has emerged from the historical discourse. Recently, however, paleoclimatic proxy data point to climatic changes as a major exogenous triggering factor for weakening the power of Rome and for provoking the Migration Period-and by this, eventually, the downfall of the Western Roman Empire. According to Harper [4], "the search to identify how climate change has shaped human history is in full swing ... " (p. 566).

Commonly, the year AD 476, when the last Western Roman Emperor (a child around ten years old, named Romulus Augustulus) was deposed by Odoacer (the first King of Italy) is taken as the terminal date of the Western Roman Empire (or the Roman Empire in general). Its decline and fall, however, was a long-lasting and complicated progression of many intertwined events. Against the backdrop of the complexity, we can hardly expect a simple answer and one single cause for the decline and fall of this civilization; a combination of multiple different factors is more realistic. Historians distinguish between various internal and external pressures, but are uncertain about a decisive force for the downfall.

The fall of Rome can be interpreted as a societal collapse of a complex human society. Such a disintegration may be relatively abrupt or more gradual. According to the Anna Karenina principle $(\mathrm{AKP})$, many factors are usually involved in such processes [5]. The first sentence of Leo Tolstoy's novel, Anna Karenina, is: "Happy families are all alike; every unhappy family is unhappy in its own way." Here, Tolstoy means that for a family to be happy, several key aspects must be satisfied. If there is a deficiency in any one or more of these key aspects, the family will be unhappy (in its own way). If an analogy for the "unhappy family" was the Roman Empire, the AKP suggests it declined and fell in its own way. According to AKP, at least one factor would have been sufficient for the fall of Rome (which would then be unique in its own way), but many factors were actually involved.

In past decades, the model of a collapse of the Roman Empire has been replaced by a model of a gradual transition moving seamlessly from Late Antiquity into the early Middle Ages [6]. Recently, however, the end of Rome has been seen as a most radical and violent process, in which the Empire could not withstand the barbarians [7]. The idea of accommodation of the invaders and their peaceful coexistence with the Romans provides a more favorable view on European history, but the sharp decline in the material culture (the quality of buildings and roofs, pottery, coins, etc.) during Late Antiquity tells another story [8]. After a period of downplaying the importance of invasions and the amount of violence involved, many historians now agree that the barbarian migration played a decisive role as a triggering factor for the downfall of the Western Roman Empire [7,8]—and it is at this point that climate change enters the story.

Since around AD 370, a mobile federation that coalesced by the name of "Huns" arrived in the Danube area and sparked massive external pressure on the borders of the Roman Empire. In response to the migration of the Huns, tens of thousands of Goths begged for permission in AD 376 to cross the Danube into the Roman Empire. Their integration failed, and the Roman army was defeated in AD 378 near Adrianople (now Idirne, Turkey) with Eastern Emperor Valens (AD 328-378) falling in the battle. After this tragedy, Gothic tribes migrated through the empire and eventually sacked the city of Rome in AD 410. At about the same time, the Roman rule of Britain stopped. The first migration phase was followed by successive waves of migration of Alans, Alemani, Franks, and Vandals, who increasingly destroyed the Roman hegemony in the West. Germanic tribes carved out kingdoms in Gaul, Iberia, and North Africa. As a consequence of the loss of hegemony in many provinces, the taxes yield (most important for funding the Roman army, which was forced to hire more and more Germanic soldiers) 
decreased substantially [7]. The loss of North Africa as the Roman "breadbasket" additionally reduced the economic power of the Empire.

The unsolved problem of the succession to the Roman throne caused civil wars and usurpation, resulting in a general weakening of the Roman political and military system. The large gap between poor and rich, the increasing battle fatigue of Roman citizens, and missing readiness for action presumably contributed much to the downfall. However, many of such drawbacks lasted for a long time and did not change dramatically over time. Therefore, it is difficult to assert at what time the decline of the Roman Empire had begun. Also, we have to distinguish between the end of the Western Roman Empire, on which this analysis is mainly focused, and the fall of the Eastern Roman Empire (Byzantine Empire), which survived the fragmentation and fall of the Western part. The year 1453, when Constantinople was conquered by the Ottomans, is commonly seen as the end of the Byzantine Empire; however, most of the Eastern part of the Roman Empire was lost to the Arabs already in the 7th century, downgrading it to a regional power. Thus, if we speak hereafter of the collapse or fall of the Roman Empire, we are meaning to say the Western Roman Empire.

At the same time, when the power of the Roman Empire weakened, the strength of the Germanic tribes increased considerably. During the long-lasting influence of the Romans, their agriculture significantly improved due to large population growth. The numerous smaller Germanic tribes at the beginning of the Roman occupation increasingly organized into larger units, guided by distinct ruling classes. Many of their soldiers had served in the Roman army and adopted Roman tactics of war and weaponry. Altogether, the economic, political, and military power of the Germanic people had increased fundamentally. However, there was not a titanic battle of Roman forces against Germanic tribes. "Romans were as often at war among themselves as they were with the Germanic invaders. And the latter were often happy to ally with Roman forces against other Germanic tribes" [9]. Eventually, this overburdened the resilience of the Western Roman Empire (i.e., its capacity to respond and to recover). According to Brooke [10], "the overall effect was the militarization of the collapsing society, as magnates raised armies to capture more of the shrinking surplus. Some of these new men were "barbarians", Germans, and others from across the frontier, who were first invited as mercenaries to build up the ranks of the waning Roman army, and then made their move to grab the power" (p. 346).

The question arises as to whether there was a driving force, which was mainly responsible for the fall of Rome; whether this question is useless against the backdrop of the complexity of the process; or because, at some point or another, all great powers have declined until now. Asking the other way around also makes sense: What were the crucial preconditions for the Roman Empire lasting for such a long time? Such questions have provoked a long-lasting scientific discourse among scholars in the field of history and neighboring sciences.

At the end of the 18th century, the English historian Edward Gibbon (1737-1794) published six volumes of a book series entitled "The history of the decline and fall of the Roman Empire", which has attracted a large amount of attention to date [11]. Gibbon discussed the supposed destructive role of the Christian religion at the end of the Roman Empire. His work has been criticized for its view of Christianity, resulting in the banning of the book in several countries. Since Gibbon, a multitude of further reasons have been discussed, with decadence, decline of the birth rate, pandemic plague, class conflict, economic decline, bureaucracy, burden of taxes, civil wars, and corruption being the most important ones.

In the year 1917, Ellsworth Huntington (1876-1947), a professor of geography at Yale University, published an article in the "Quarterly Journal of Economics", entitled "Climatic change and agricultural exhaustion as elements in the fall of Rome" [12]. His new interdisciplinary approach was based on tree-ring data and various geological indicators of the climate in the past. He believed that climate change contributed much to the fall of the Roman Empire. Huntington has been criticized as a representative of the so-called climatic determinism. His belief that the climate of North-Western Europe was ideal, had powerful connections to colonialism and may have been taken to justify the downgrading of less advanced nations. 
With Huntington's 1917 paper, the possible role of anthropogenically-caused climate change in antiquity was posed. However, in the second half of the 20th century, the conventional wisdom became that environmental change played no such decisive role. Climate change has remained a marginal candidate for explaining the end of the Western Roman Empire until recent times. Previously, the discussion had been limited to the scientific community of archeologists and historians, mainly based on archeological artefacts and written records. However, within the past two decades, climate change research has gathered a large amount of paleoclimatic records serving as proxy data for the climate in the past, which may potentially be useful in shedding light on unsolved historical questions, like the possible causes for the fall of Rome and other civilizations.

For many years, scientists have had limited access to paleoclimatic data, and thus presumed that the climate had changed little since the warming up after the last Ice Age. However, new climatology has revealed that the Holocene climate was actually constantly on the move. Note that ancient climate change should not be confused with anthropogenic climate change, which is a recent problem caused by the various heat-trapping greenhouse gases released into the earth's atmosphere as a result of industrialization.

Half a century ago, the British meteorologist Hubert Lamb argued that he had identified the Medieval Warm Period, which was a significant factor involved in shaping medieval history. Meanwhile, a large amount of climate proxy data exists, which indicate that there were changes in temperature and precipitation regimes in the Mediterranean area and Northern Europe during the Late Antiquity. The data revealed that the climate was not stable during the Late Holocene (the past 3000-4000 years) and particularly during the time span of the Roman Empire. The Roman Empire reached its maximum peak during a phase of warm, wet, and stable climate, fostered by high, stable solar activity and weak volcanic activity (the Roman Climate Optimum or Roman Warm Period). Meanwhile, this period has been widely documented by a multitude of paleoclimatic data based on various climate archives and also by written records.

For example, in the first century AD, the naturalist Pliny the Elder noted that beech trees, usually growing in the lowlands, had become mountain plants. This corresponds to the documented biotopes of thermophilic insects and the evidence of Roman viticulture in Britain. For an agrarian society, climate is a fundamental condition. "As the Romans stretched their empire to its limits, they had no idea of the contingent and parlous environmental foundations of what they had built" [13] (p. 15). From the middle of the second century AD, "one of the most dramatic sequences of climate change in the entire Holocene" set in. "At crucial junctures, climate instability pressed on the empire's reserves of strength and intervened dramatically in the course of the events" [13] (p. 15). Some scholars propose a period of gradual cooling and increasing climate variability, beginning approximately at AD 250. According to Harper [13], the Roman Climate Optimum (BC 200-AD 150) moved smoothly into the Roman Transition Period (AD 150-AD 450), which was a period of climate disorganization, followed by the Late Antique Little Ice Age (AD 450-AD 700).

The bibliometric analysis of this study aims to visualize the scientific discourse about the possible role of climate change for the collapse of the Western Roman Empire using well-established bibliometric methods. The relevant publications have been retrieved from a multidisciplinary literature database, and were analyzed to explore the role of climate change (natural or man-made climate shifts) for the fall of Rome. These explorations can be done also in overviews, which summarize the corresponding literature. However, literature overviews published by single experts in a specific field are in danger of bias toward their own background and interests. The bibliometric approach provides the "wisdom of the crowds", and reveals the status, as well as the time evolution, of the experts' consensus and disagreement.

The current study is based on the complete set of the relevant literature covered by the Web of Science (WoS, Clarivate Analytics). In recent years, some other multidisciplinary literature databases have entered the market besides WoS. The two primary competitors to the WoS are Scopus (www. scopus.com) from Elsevier, and Google Scholar (GS) (http:/ / scholar.google.com/) from Google Inc. 
Searches in Scopus delivered almost identical results, without decisive advantages over the WoS. Scopus and WoS have the advantage of sophisticated retrieval languages, with comprehensive search possibilities. These possibilities were decisive for our literature search and not available in GS.

A major bias of the study is that most of the historical works on the fall of Rome have been published as books or book chapters not covered by the WoS (and therefore are scarcely considered in the bibliometric analyses). The publication set analyzed here predominantly covers literature related to climate research. Recently published articles mainly come from research in the geosciences, and are not yet being embedded in the long-lasting scientific discourse of historians.

The analytical approach of this study follows that of a former study, in which we applied bibliometric methods to analyze the collapse of the Maya civilization in connection with climate change [14]. To the best of our knowledge, no bibliometric study dealing with the end of the Roman Empire has appeared until now. Thus, this study is intended to be a starting point for using bibliometric data on research regarding this issue.

\section{Materials and Methods}

\subsection{Dataset Used}

Searching all the papers related to specific research fields or topics in literature databases can be quite challenging (to avoid confusion with the document type "article," the term "paper", rather than "article", is used throughout this manuscript for any kind of journal-based publication). Completeness or recall (i.e., retrieving all relevant papers) and high precision (i.e., retrieving solely relevant papers) are inversely related and mutually exclusive [15]. This basic connection between completeness and precision precludes a much "cleaner" publication set (i.e., more relevant papers and concurrently less non-relevant papers).

As a first step in the literature search, we searched for publications dealing with the decline and fall of the Roman Empire in general (i.e., independent of the impact of the climate). We aimed to quantify the order of magnitude of the research papers accessible via the WoS literature database. Our search query was based on title word searching, and excluded papers dealing with the end of the Roman Republic rather than the end of the Roman Empire (see the WoS search query I in Appendix A). Title word searching is much more specific than topic searching (i.e., including abstract words and keywords) but probably incomplete. By refining the answer-set, 1123 publications were retrieved at the date of searching (1 April 2018). Most of the publications were book-related publications: book reviews (798), book chapters (50), and books (10); only 257 publications were research papers, which have been assigned to the WoS document types "article" (224), "proceedings paper" (25), and "review" (12). This clearly demonstrates the excessive importance that books have in historical research.

In the second step of our literature search, we searched more specifically for papers dealing with the decline and fall of the Roman Empire in connection with a changing climate or environment. We applied a combination of title word and topic searching by alternately searching for terms related to the fall of Rome and the impact of the climate within the titles and as topics, respectively. For completeness, many synonyms for the phenomenon of the decline and fall had to be considered as search terms. However, many terms were not specific enough (e.g., the term "end") and resulted in a large amount of non-relevant papers. Therefore, the corresponding search terms had to be restricted to title words; for topic searching, we applied a suitable adjacency operator (see the WoS search query II in Appendix A). From that we retrieved 46 papers, from which we selected 10 key papers, which primarily dealt with climate change in connection to the fall of Rome, with most of them reviewing the current state of knowledge on this topic:

1. Moravcsik, A.: The fate of Rome: Climate, disease, and the end of an empire (2018) [16]; book review of [13] (at the date of searching, the original book [13] had not yet been covered by the WoS).

2. Decker, M.J.: Approaches to the environmental history of Late Antiquity, part II: Climate change and the end of the Roman Empire (2017) [17]. 
3. Drake, B.L.: Changes in North Atlantic oscillation drove population migrations and the collapse of the Western Roman Empire (2017) [1].

4. Storey, R. \& Storey, G.R.: Rome and the Classic Maya: Comparing the slow collapse of civilizations (2017) [18].

5. Harper, K.: The environmental fall of the Roman Empire (2016) [19].

6. Izdebski, A. et al.: The environmental, archaeological and historical evidence for regional climatic changes and their societal impacts in the Eastern Mediterranean in Late Antiquity (2016) [20].

7. McCormick, M. et al.: Climate change during and after the Roman Empire: Reconstructing the past from scientific and historical evidence (2012) [21].

8. Buentgen, U. et al.: 2500 years of European climate variability and human susceptibility (2011) [22].

9. Brown, N.: Climate change and human history - Some indicators from Europe, AD 400-1400 (1994) [23].

10. Huntington, E.: Climatic change and agricultural exhaustion as elements in the fall of Rome (1917) [12].

One basic problem of the literature search was that our topic-the role of climate change in connection with the decline and downfall of the Roman Empire-did not represent a common research topic for various reasons: (1) The number of highly relevant papers published as research articles in scientific journals was rather low, and much of the relevant literature appeared in books or book chapters, usually as a secondary topic; (2) many of the relevant papers dealt with the reconstruction of the complete Late Holocene climate, and included the period of Late Antiquity only as a minor time period. They mentioned the relevance of their results to the fall of the Roman Empire, but did not discuss this in great detail.

For this reason, we searched for literature concerning paleoclimatic research in combination with the time period of the Roman Empire and Late Antiquity, but independent from the fall of Rome (see the WoS search query III in Appendix A). We applied a more sophisticated method, which comprised of a preliminary search for literature relating to our topic and a renewed search based on the synonyms revealed by text analysis of the relevant papers (see [24]). This search strategy is called "interactive query formulation" [25]. As a result, we retrieved 263 potentially relevant candidates, from which we manually selected 57 highly relevant papers. In the fields of archeology and history, a large portion of literature is not published as research papers, but as books or book chapters. Thus, our assumption is that there exist many more relevant publications (especially books mostly not covered by the WoS as database records, but as references cited in journal articles), which are not included in our previous answer-sets.

To overcome this limitation, we extended our search for relevant literature by considering additionally: (1) all references cited by the 10 key papers; and (2) all citing papers of the 10 key papers. We assumed that further potentially relevant publications are among the cited references and the citing papers of these highly relevant papers. The cited references and the citing papers were searched via their WoS accession numbers. To exclude the non-relevant papers (e.g., the key papers are not only cited in combination with the fall of Rome), we combined the answer-sets of the cited and citing papers with the string, "TS $=$ Rom $*$ AND TS $=\left(\right.$ climat $^{*}$ OR environment $\left.{ }^{*}\right)$ ". By this we retrieved further potentially relevant papers covered by the WoS as database records. We also manually inspected all cited references of the 10 key papers for relevant literature covered by the database only in the form of references. We detected 18 additional publications (especially books or book chapters) not retrieved by the search queries II and III.

To receive the final publication set for this study, we merged the publications retrieved by applying the WoS search queries II and III and selected relevant papers from the references and citing papers of the 10 key papers $(10+57+18)$, receiving a final publication set of 85 papers. The complete list of references for these papers are given in Appendix B. The search strategy is presented in Figure 1 as a flow diagram. 


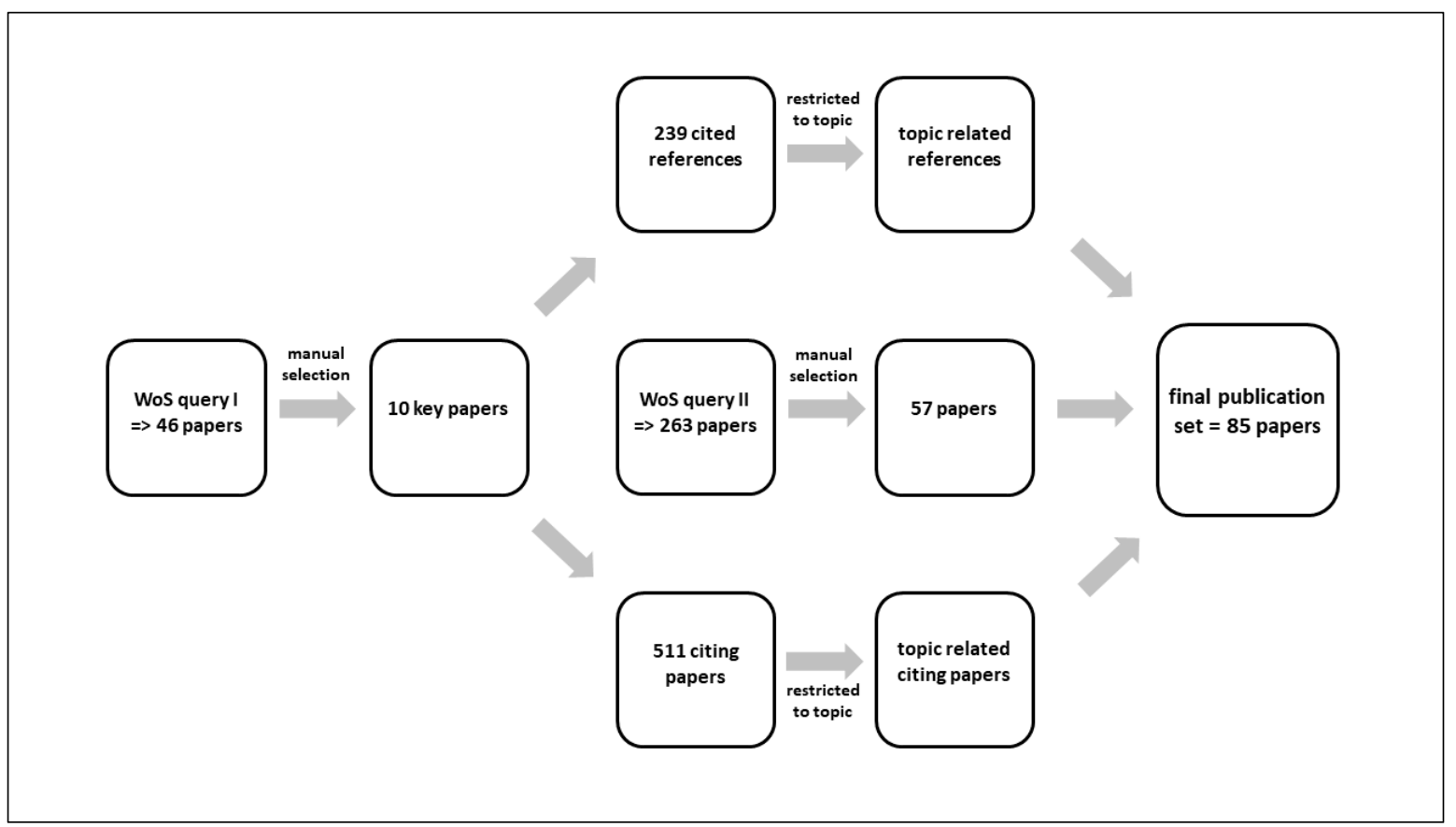

Figure 1. Flow diagram of the search and selection steps.

Of the 85 papers dealing with the decline and fall of the Roman Empire in connection with climate change, 62 papers appeared since 2010, demonstrating the recentness of this research topic. More than $60 \%$ of the papers were assigned to the WoS research area "Geology" (52), 40\% to "Physical Geography" (34), and 12\% to "Environmental Sciences Ecology" (10); only 7\% appeared in the research area "History" (6). Note that many papers are assigned by WoS to more than one research area. The most important journals in terms of the total number of papers published are the "Quaternary Science Reviews" (10), “Climate of the Past" (7), and "Holocene" (5). "History Compass", on rank 6 , is the first journal of this ranking outside the natural sciences. The analyses of the research areas and journals demonstrate that the natural sciences (especially geoscience, ecology, paleoclimatology, and meteorology) entered research in archeology and history, and have boosted research around a long-discussed, but unsolved question. Before paleoclimatic data entered, there was a long-lasting and often very controversial discussion, which was mainly based on archeological and written sources. However, "these documents began to lose their importance gradually in the writings of a historical nature and were replaced by new documents and new approaches elaborated and exploited by the exact sciences" [26] (p. 49). The growing number of research on climate change delivered the preconditions needed to analyze the role of climate change on the decline and fall of ancient civilizations.

The citing publications $(n=1845)$ of the papers of the final publication set (85 papers) were analyzed with regard to their WoS research areas. The vast majority of the citing papers appeared in the geosciences research areas; only 46 citing papers $(2.5 \%)$ were assigned to the WoS research area, "History". The citing papers primarily discussed paleoclimatic analysis methods and data from larger time-periods (e.g., some millennia), with no specific focus on the fall of Rome.

\subsection{Visualization of Authorships and Research Topics}

We used the VOSviewer software 1.6.5 [27,28] for mapping the authors and keywords of the literature dealing with the decline and fall of the Roman Empire in connection with climate change. First, we analyzed the co-authorship network in our publication set. The co-authorship map is based on concurrent occurrences (co-occurrences) for positioning the nodes (i.e., the authors) on the maps. The distance between two authors is approximately inversely proportional to the amount of co-authorships. Hence, authors who have frequently co-authored tend to be found closer to each other. 
The size of the nodes is proportional to the number of papers published by an author. The nodes on the maps are assigned by VOSviewer to clusters based on a specific cluster algorithm. These clusters identify closely related nodes, whereby each node is assigned to only one cluster. The corresponding method, which we used for revealing the thematic content of the publications, was based on the analysis of "keywords plus", assigned by the database producer Clarivate Analytics. The keyword map is based on co-occurrences for positioning the corresponding keywords on the map. The distance between two keywords is approximately inversely proportional to the relatedness of the keywords (relatedness in terms of co-occurrence). Hence, keywords with a higher rate of co-occurrences tend to be closer to each other. The size of the nodes is proportional to the number of papers with a specific keyword.

\subsection{Visualization of the Citation Network}

We used CitNetExplorer [29,30], a bibliometric tool to visualize citation networks, to analyze the development of research dealing with the decline and fall of the Roman Empire in connection with climate change over time. The tool builds on Eugene Garfield's work on algorithmic historiography and the corresponding program, HistCite (however, this program is no longer in active development nor is officially supported). The citation network displays linkages (citations) among the relevant papers, represented by circles. The connections between the nodes indicate, which later papers cited certain earlier papers. The network also illustrates how the nodes are positioned on the pathways between the papers (this is called centrality). The interconnectedness helps to identify central publications.

\subsection{News Mentions}

Since citations measure the impact of papers exclusively within science, we also considered in this study news mentions to identify papers, which had impacts beyond science. Books could not be included here, however, and most of the news counts were dominated by journal articles. News items were mainly linked to papers based on direct links or unique identifiers, such as DOIs (Digital Object Identifiers). The company Altmetric [31] tracks mentions of scientific works in online media, and among them, news outlets (e.g., BBC or The Times). Altmetric shared with us a snapshot of their data on 2 October 2017. The data were used to analyze how often the publications in our set were mentioned in news outlets.

\section{Results}

\subsection{Estimated Number of Publications}

Based on the publication set retrieved by search query I, we tried to quantify the order of magnitude of the research papers dealing with the downfall of the Roman Empire in general. Title word searching was highly specific but incomplete. However, our experience in database searching enabled a rough approximation of the amount of research articles we would find relating to our topic of analysis and published until present. As a rule of thumb, compared to title word searching, topic searching in literature databases normally results in publication sets, which are one order of magnitude larger than usual. Compared to titles, abstracts have, on average, roughly ten times more text. Therefore, we conclude that the body of relevant research articles roughly amounts to 2500 papers.

\subsection{Co-authorship and Keyword Maps}

We analyzed the final publication set of 85 papers dealing with the fall of Rome or the time period of the Roman Empire, respectively, in connection with climate change. An inspection of the author affiliations within our publication set shows that this has induced much interdisciplinary collaboration (there were, on average, five authors per paper). The co-authorship map of all authors is presented in Figure 2, and can be further inspected by zooming in (see https: / tinyurl.com/y87aojfx). 


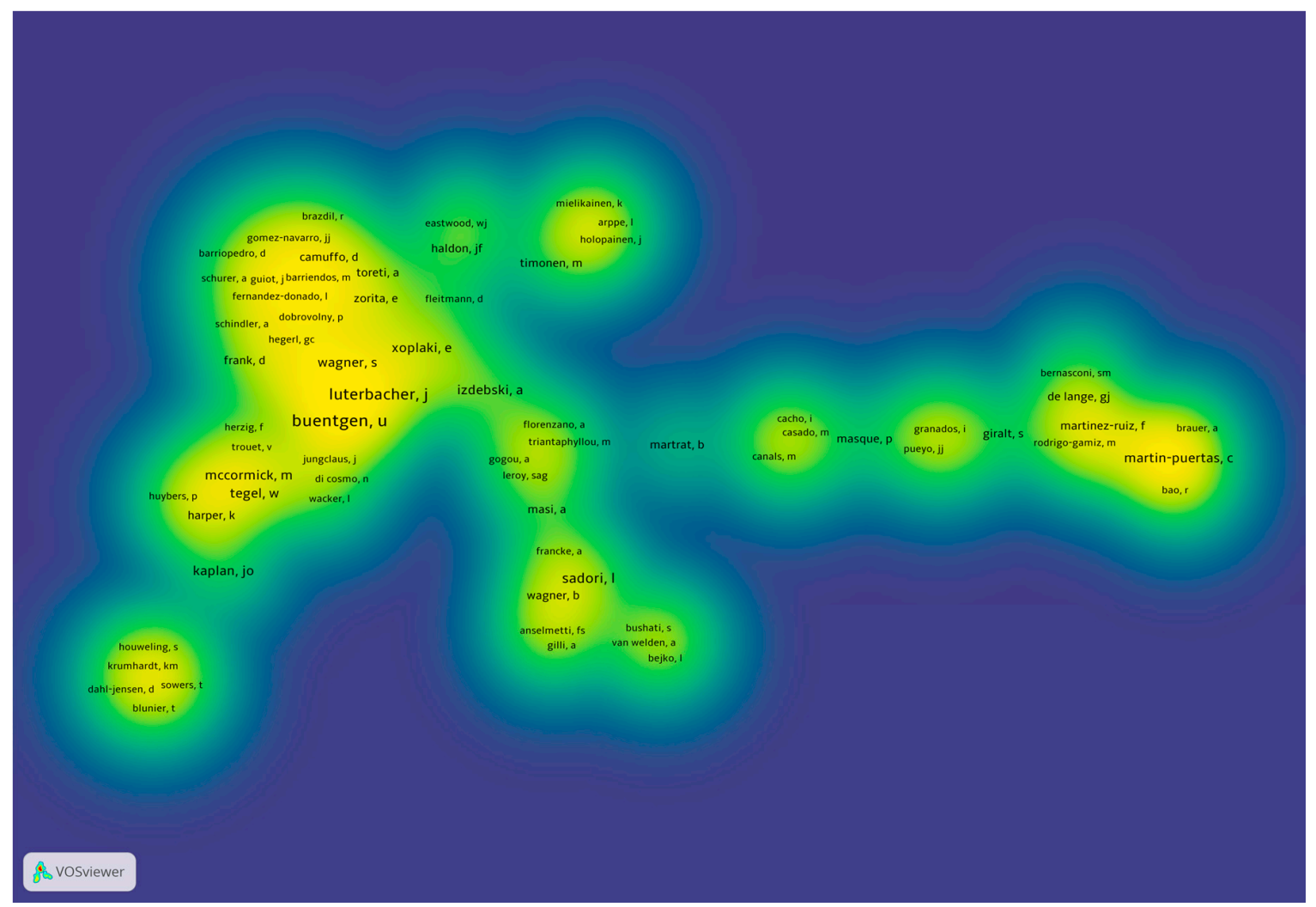

Figure 2. Co-authorship map of all authors (435) from the 85 papers dealing with the fall of Rome or the time period of the Roman Empire in connection with climate change (the minimum number of papers containing a specific author is one). Readers interested in an in-depth analysis of our publication set can use VOSviewer interactively and zoom into the clusters via the following URL: https: / tinyurl.com/y87aojfx. Source: WoS, VOSviewer.

Figure 2 reveals a series of collaborations on which the papers of our publication set were based. In the co-authorship map, Buentgen, Luterbacher, and Sadori appear most pronounced as the cooperating authors. Top left: the cooperation of Jürg Luterbacher (climate researcher) with many others on the reconstruction of European summer temperatures since Roman times [32]; center left: the cooperation of Ulf Buentgen (climate researcher) with Michael McCormick and Kyle Harper (both historians) on climate change during and after the Roman Empire [21], and with Jürg Luterbacher and many others on 2500 years of European climate variability [22]; bottom left: a work on natural and anthropogenic variations in methane sources during the past two millennia [33]; center left: the cooperation of Adam Izdebski (historian) with Büntgen, Luterbacher, and others for a paper on better communication between archeologists, historians, and natural scientists [34]; top center: a Finnish work on volcanic dust veils in the sixth century [35]; center bottom: the cooperation of Laura Sadori on vegetation history and the paleoclimate in Greece [36] and on human-climate interactions in the Central Mediterranean region [37]; center right: the work on sea surface temperature variability in the Central-Western Mediterranean Sea during the past 2700 years [38], on climate reconstruction for the past two millennia in Central Iberia [39], and on climate variability in the Western Mediterranean during the Late Holocene [40]; center far right: the works on Late Holocene climate variability in Southern Spain and on the Iberian-Roman Humid Period [41-43]. Some authors do not appear without zooming into the clusters (see https:/ / tinyurl.com/y87aojfx). For example, center left: the work of Jan Esper on Northern European summer temperature variations from integrated tree-ring density records [44] and the cooperation of Fredrik C. Ljungqvist (historian) with Buentgen and Luterbacher. However, his paper on the reconstruction of the temperature variability in the Northern Hemisphere during the past two millennia [45] was published without co-authors. 
We produced a keyword map for a rough content analysis of the 85 papers dealing with the fall of the Roman Empire in connection with climate change, which we present in Figure 3 (see https: //tinyurl.com/ybrbmqc6). This map is based on "keywords plus", which is suitable for an overview of the thematic content. The mapping of "all keywords" delivers a finer-grained keyword cloud, but "keywords plus" has the advantage of a higher degree of standardization because they are provided by the database provider, rather than the authors.

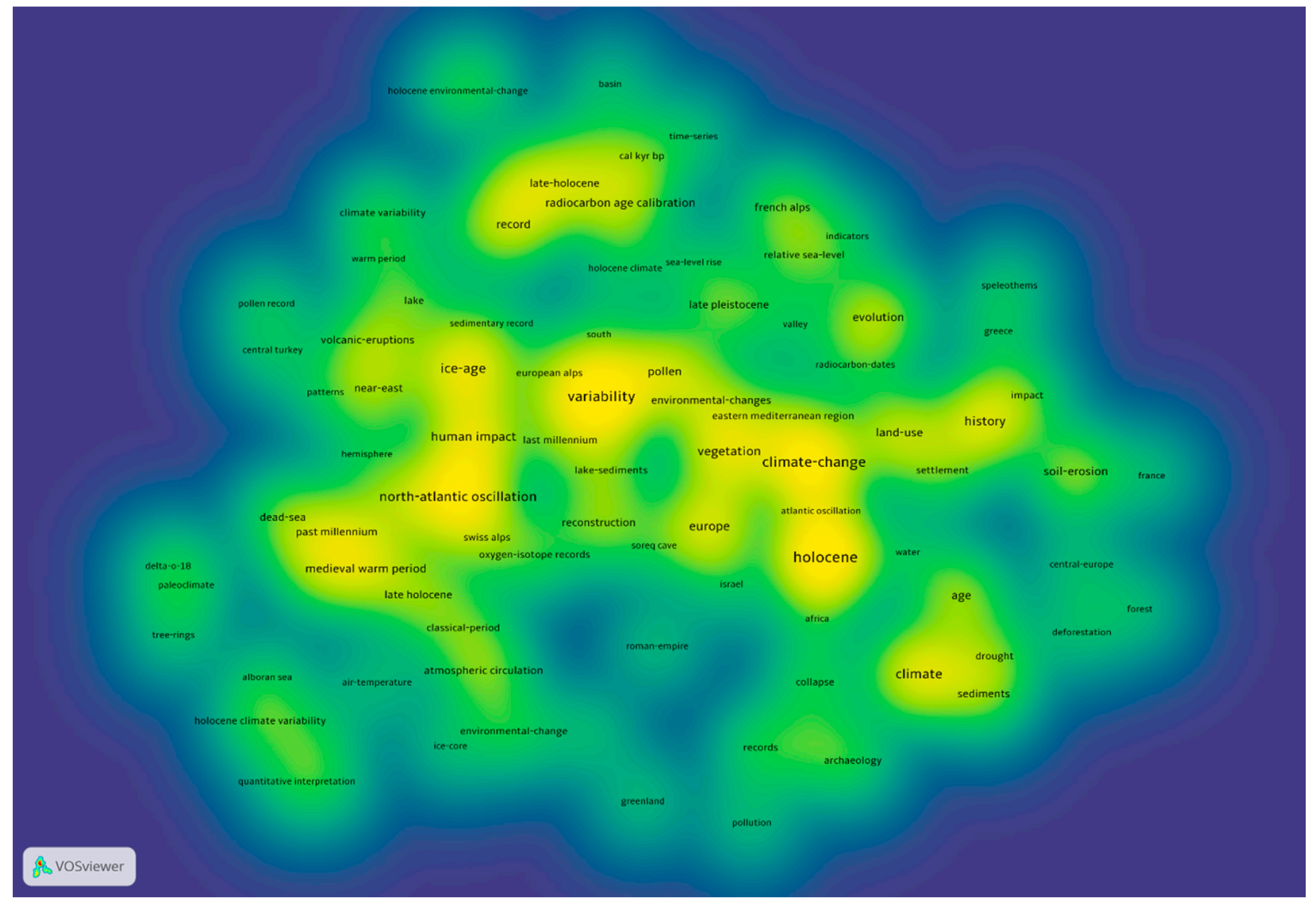

Figure 3. Co-occurrence map of "keywords plus" (95 out of 439 keywords) from the 85 papers dealing with the fall of Rome or the time period of the Roman Empire in connection with climate change for a rough content analysis (the minimum number of co-occurrences of a keyword is two). Readers interested in an in-depth analysis can use VOSviewer interactively and zoom into the clusters via the following URL: https: / / tinyurl.com/ybrbmqc6. Source: WoS, VOSviewer.

Besides the keywords around the search terms (Roman Empire, collapse, climate), it can be seen that some related terms (climate change, variability, human impact) are most pronounced. Also, meteorological terms (atmospheric circulation, north-atlantic oscillation) appear as pronounced keywords, showing their importance within the discussion. The density map reveals, at a glance: (1) the various paleoclimatic indicators and dating methods applied (pollen, tree-rings, sediments, speleothems, radiocarbon); (2) the causes and impacts of a human-induced changing climate (drought, deforestation, vegetation, land use, soil erosion); (3) the locations of the records analyzed (Africa, Greece, Israel, Turkey, Dead Sea, Eastern Mediterranean Region, Near-East, European Alps, Greenland); (4) the relevant time periods (classical period, warm period, Holocene, Late Holocene); and (5) volcanic eruptions, and various other relevant keywords. A co-occurrence map of "all keywords" reveals further terms, as, for example, additional sites (e.g., Central Italy, Central Spain) and more paleoclimatic records (e.g., ice-core). 


\subsection{Citation Network}

We present in Figure $4 \mathrm{a}$ the citation network of the 85 papers dealing with the end of Rome or the time period of the Roman Empire in connection with climate change. The inserted crop shows the network of the papers at center bottom in more detail (with all author names readable) and Figure $4 \mathrm{~b}$ shows, as an example, the specific references cited by Decker [17] which are highlighted.

The citation network of the 85 papers dealing with the end of Rome in connection with climate change shows, which papers cite which other papers within the publication set (Figure $4 a, b)$. The citations are directed from the bottom (present) to the top (past).

Discussing the evolution of the scientific discourse, we start with the earliest publication from 1917 [12]. Huntington's new interdisciplinary approach was based on tree-ring data and geological indicators of the climate in the past (alluvial deposits, lake strands, the amount of salt in enclosed lakes, and river terraces). Huntington argued that climate change can lead to the demise of even advanced civilizations through drought, food insecurity, and damage to economic production. He believed that climate change contributed much to the fall of the Roman Empire. The climate proxy data available at his time showed that the Roman world had become drier and climatically more variable compared to the climate in prior centuries. According to his view, deforestation, soil exhaustion, and crop failure played a major role in the downfall of Rome. Huntington can be seen as a kind of forerunner in the field of climatic impact in ancient history, and may be compared with Alfred Wegener in the field of plate tectonics [46].

The next paper in Figure 4 did not appear until decades later (1951) [47], discussing the decline of North Africa since the Roman occupation. Murphey questioned whether the degree of climate fluctuations suggested by Huntington was responsible for the decline of North Africa, and pointed to the human factor for an explanation. Next in the figure comes a more general paper by Neville Brown [23] on climate change and human history within the time period AD 400-1400. With regard to the Roman World and on the basis of the sparse paleoclimatic data at that time, Brown states: "So overall, the signs are of aridity and cold sufficient to stimulate Völkerwanderung [Mass Migration] in inner Eurasia that bore so hard on the Roman and other settled realms. A well-recognized driving force was the migration of Hunnish tribes out of East and the central Asia" [23] (p. 39). Against the backdrop of some recent publications discussed below, this was a farsighted statement. The first paper in the network presenting paleoclimatic data for the reconstruction of the past climate with regard to the Roman Warm Period and the Dark Ages Cold Period appeared at the beginning of the 21st century [48]. This paper discusses Holocene climate variability based on speleothem records from South-West Ireland.

Since around the year 2000, a multitude of papers on climate change within the past two millennia based on paleoclimatic data have been published. The paleoclimatic records (mineral deposits in caves called speleothems, lake sediments, river sediments, ocean sediments, pollen samples, tree-ring data, glacier movements, ice-core samples, etc.) were taken on many different geographical sites of the Roman Empire: Central Italy [49], Central Iberia [39], North Western Iberia [50], Central Spain [51], Southern Spain [41,42], Austrian Alps [52], Croatia [53], Greece [54], Southern Levant [55], Israel [56-58], Egypt [59], North Africa [26], Central Mediterranean Sea [60], Albania [37], Western Mediterranean [40], Eastern Mediterranean [20,61], Western Germany, Eifel Maar [62], and others. Some papers dealt with the reconstruction of European summer temperatures since Roman times, based on climate proxy data $[32,44,45,63]$. Reale $[64,65]$ constructed a Mediterranean vegetation map representing the conditions of two millennia ago. Their general circulation model suggests that deforestation around the Mediterranean over the past 2000 years contributed to the dryness of the current climate. 


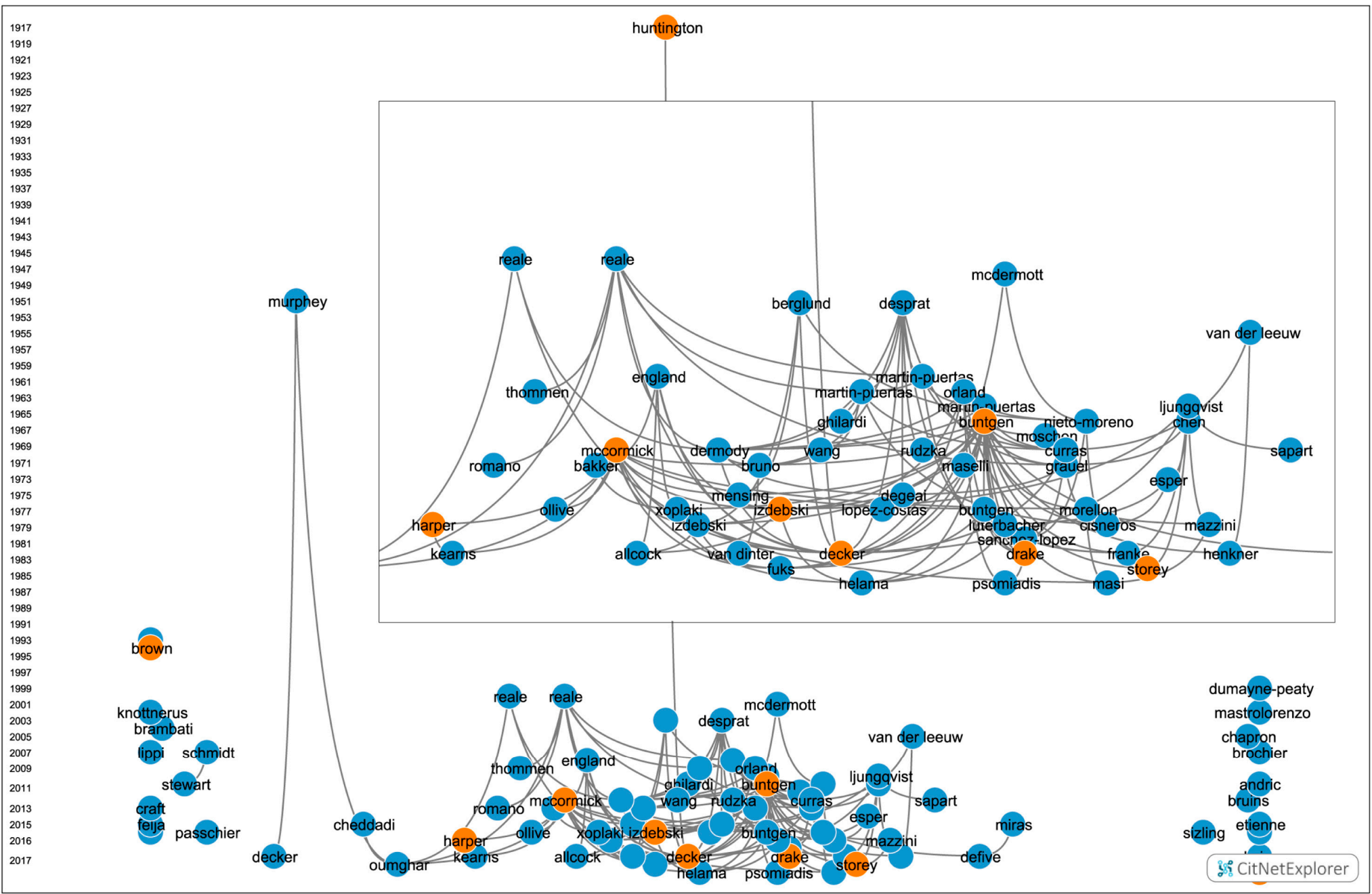

(a)

Figure 4. Cont. 


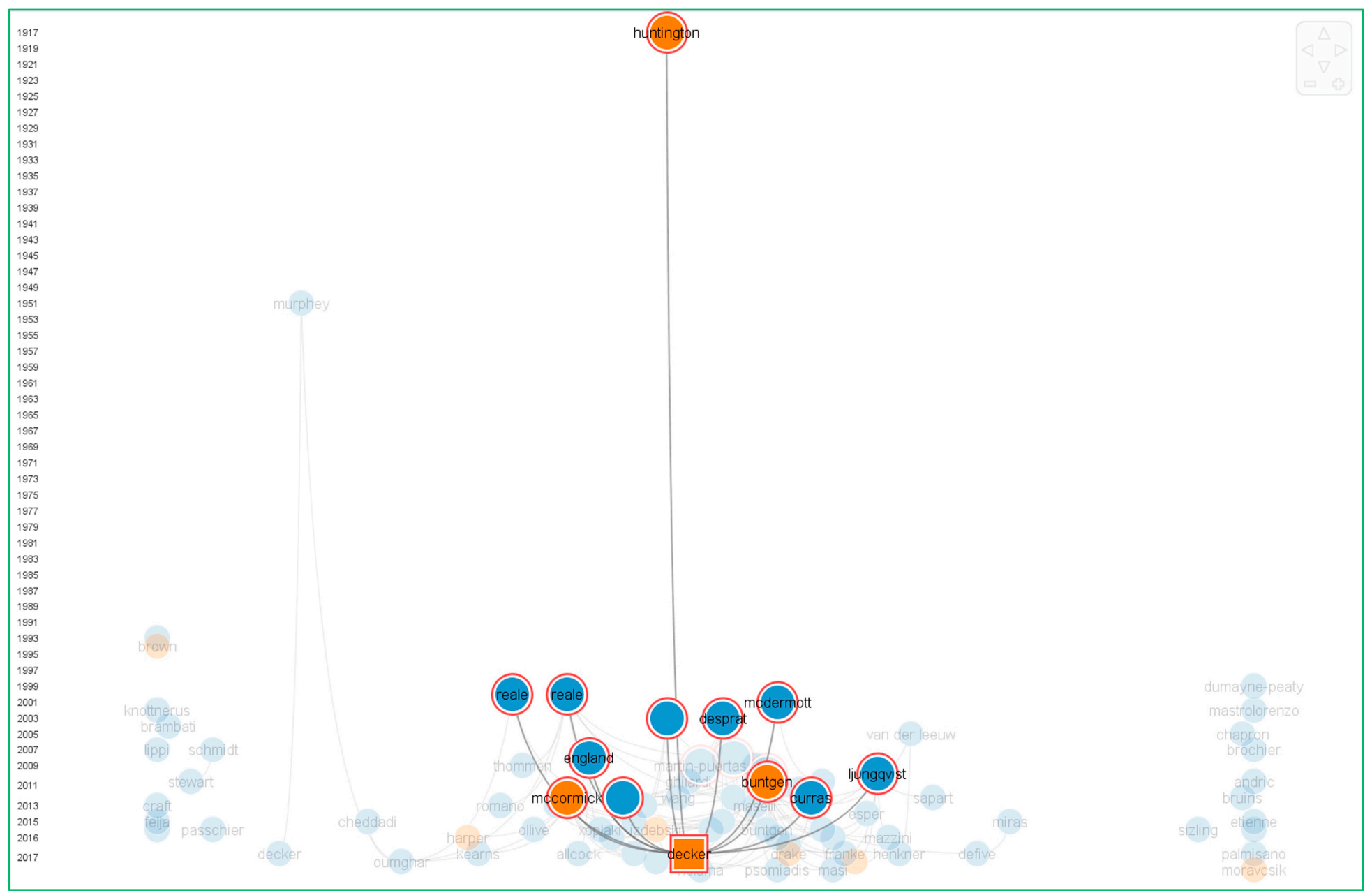

(b)

Figure 4. (a) Citation network (137 citation links) of the 85 papers dealing with the fall of Rome or the time period of the Roman Empire in connection with climate change (excluding the non-matching cited references). A crop of the network of the papers at center bottom has been inserted for showing all author names. Orange: 10 key papers. The coloring has been performed manually within CitNetExplorer. Source: WoS, CitNetExplorer. (b) Screenshot of the citations of Decker [17]: Decker cites 11 other papers out of our publication set of 85 papers (four other key papers). 
Two review papers [21,22] are most important in the citation network: Based on tree-ring data, Büntgen et al. presented a reconstruction of Central European summer precipitation and temperature variability over the past 2500 years [22]. Trees add two growth layers to their girth annually, which change during abnormal cold or dry episodes in measurable ways. According to these data, the period of Roman prosperity is characterized by warm and wet summer conditions. Since around AD 250, increased climate variability coincided with the demise of the Western Roman Empire. According to Büntgen, "exceptional climate variability is reconstructed for 250 to 550 AD and coincides with some of the most severe challenges in Europe's political, social, and economic history, during the Migration Period. Distinct drying in the 3rd century paralleled a period of serious crisis in the WRE [Western Roman Empire] marked by barbarian invasion, political turmoil, and economic dislocation in several provinces ..." "[22] (p. 580).

McCormick et al. published an article that "represents a kind of 'white paper', presenting the first multi-proxy baseline synthesis of what is now known with some confidence about climate conditions across the Roman and post-Roman world from ca. 100 BC to 800 AD" [21] (p. 172). The relevant materials and methods are presented in the detailed appendix of the McCormick paper. According to McCormick's synthesis, the centuries of the rise of the Roman Empire are characterized by exceptional climate stability, with some regions enjoying unusually favorable conditions. From the first century $\mathrm{BC}$ to the second century AD, the climate of the Western Roman Empire was warmer than in the following centuries. The more frequent and extensive Nile floods during this period, which were most important conditions for cereal production, enabled Egypt (besides the other provinces in North Africa) to become the "breadbasket" of the Roman Empire. As an agrarian society, deforestation and soil exhaustion certainly put some stress on its landscapes. However, anthropogenically-driven climate change is currently not seen to have been a leading force in the fall of Rome [10].

For the period from AD 200 to AD 400, when severe economic, political, and military crises came about, many proxy data reveal a cooler and dryer climate for the north-western provinces, and a shift away from the stability of the previous centuries [21]. Greenland Sea ice and solar activity both indicate a cooling episode in the fifth century. Volcanic eruptions may have caused episodes of rapid climate change disrupting food production, but their political impact is unclear. They may possibly have played no major role for the decline before the distinct volcanic event in AD 536, when the Western Roman Empire had already collapsed. For the eastern provinces, some proxy data indicate increased moisture from around AD 400, which is the most critical factor in an arid environment [21]. This corresponds with the East Roman Empire's rise to economic and political dominance, and its prosperous 5th century. Paleoclimatic evidence for a 5th century drought in Southern Levant coincides with the proposed economic downturn attested to by numismatic trends [55].

The indicators for analyzing the climate of the Late Antiquity used until now are: tree-ring series from Central Asia and Europe; pollen records from Anatolia, Montenegro, and Spain; cave formations from Austria, Greece, Israel, and Turkey; Alpine glacier movements; Greenland ice cores; sediment records from European and Western Asian lakes; fluctuations in solar radiation; data on volcanic eruptions; and the recorded history of Nile floods. The solar activity of the past has been reconstructed from the concentration of the isotope Beryllium-10 in ice sheets. This isotope is produced by cosmic rays, which are depressed by higher amounts of solar activity. Volcanic emissions leave sulfate aerosols in ice cores from Greenland glaciers. The age determination of the paleoclimatic records is carried out via dedicated dating techniques (in particular, isotope-based dating and tree-ring dating). Furthermore, archeologists and anthropologists analyze the history of health and disease through chemical analysis of bones and paleomolecular methods [13].

Currently, the scope of suitable analytic methods, the number of records from the various sites, and the precision of dating are increasing substantially. However, the placing in time of the cooler and warmer periods, as well as the drier and wetter phases, is still somewhat inconsistent. "At present we may usefully, but only generally, begin to describe the climate context of the Roman world-more data from a wider spatial network, and especially good chronological control on these data, are essential 
to overcome current contradictions and uncertainties" [66] (p. 104). This holds true until present. However, the earth sciences have the potential to contribute much to the environmental history of societies and deliver the preconditions for answering the question on whether climate change (natural or anthropological) has played a decisive role in the decline and fall of the Roman Empire.

Two papers within the citation network of Figure 4 are of special interest in regard to their connection with our topic: "The environmental fall of the Roman Empire" [19] and "Realising consilience: How better communication between archeologists, historians and natural scientists can transform the study of past climate change in the Mediterranean" [34]. Two recently published review papers [1,17], and a book [18] comparing the slow collapse of the classic Maya civilization with the decline of the Roman Empire are located at the bottom. Besides the economic, political, and social dimensions of the decline of both civilizations, Storey \& Storey [18] also discuss the environmental dimension. They state that the environments of the Roman Empire and the Classic Maya are completely different and summarize that two main challenges played a role in the collapse of the Roman Empire: deforestation and soil erosion as anthropogenic components, and a general cooling trend, which all had a devastating effect on the agricultural economy. "These data suggest a general climatic downturn for the later centuries of the Roman Empire and its aftermath, reversing the Roman Warm Period" [18] (p. 180).

Michael Decker presented an overview of approaches to the environmental history of the Late Antiquity, allowing historians to discuss climatological data in the light of historical sources [17]. According to Decker, many studies support the view that Eurasia experienced a warm period (the Roman Warm Period) roughly from the fifth century BC to the fifth century AD, with annual averages being about $1{ }^{\circ} \mathrm{C}$ higher than previously. Subsequently, the climate became cooler and dryer. The various regional studies place the beginning of the cooling period at somewhat different times. "Some scholars propose a period of gradual cooling and increasing climate variability beginning ca. AD 250 and continuing into the seventh century - a phase referred to as the Migration Era Pessimum ..." (p. 2). Decker emphasizes that "environmental history holds great promise in its potential to enrich our understanding of the late antiquity" (p. 5). He states that climate history has intersected with the historical study of the transition from the ancient to the medieval world, and that "a historian today needs to be comfortable using scientific data, often considerably beyond his or her field of expertise, and in collaborating in interdisciplinary studies" (p. 2).

Since the late 1970s, measured changes in climatic humidity have been discussed in connection with long-term shifts in the North Atlantic Oscillation (NAO) as a major climatic influence in the northern hemisphere [1]. NAO is a weather phenomenon of fluctuations in the difference of atmospheric pressure and temperature at sea level between the Azores high and the Icelandic low. It is one of the great climate mechanisms of the earth. Through fluctuations in its strength, NAO controls the strength and direction of the westerly winds across the North Atlantic. Positive and negative phases of NAO affect the Eastern and Western Mediterranean in opposite ways. A positive NAO mode spins the westerlies poleward, resulting in more drought in the Western Mediterranean and more rain in North Europe. On the contrary, a negative NAO mode brings more moisture to the Western Mediterranean and a more arid climate in Northern Europe. In the Eastern Mediterranean, the effects of NAO are less distinct, because its climate is also influenced by the monsoonal system. The (distant) effect of the Eastern Mediterranean by El Niño Southern Oscillation (ENSO), an irregularly periodic variation in winds and sea surface temperatures over the tropical Pacific Ocean, has not been proven.

According to Drake [1], NAO shifted in four episodes and increased droughts in the periphery of the Roman Empire: "Periodic weakening of the NAO caused drought in regions of origin for tribes in antiquity and may have created a powerful push factor for human migration" (p. 1). The first NAO change AD coincides with the Marcomannic Wars (AD 166-AD 180), the second with the Gothic migration and the beginning of the Migration Period AD 376, and the third with the broad population movements since around AD 500. 
Some more specific papers appear to be isolated from the citation network in Figure 4: a book review [16], a foreword of a conference paper [67], and some other highly specific papers, as, for example, on the Antonine plague [68] or on the AD 472 Pollena eruption of Somma-Vesuvius [69]. Moravcsik reviewed a recently published book by Kyle Harper [13], which is not included in the citation network of Figure 4. At the date of searching, the original book had not been covered by the WoS yet. Based on a comprehensive compilation of paleoclimatic and paleomolecular data and traditional written sources, the book offers an impressive re-interpretation of the decline and fall of the Roman Empire. Harper documents the devastating spread of pandemic diseases (plague, smallpox, and tuberculosis), which, he argues, killed more than half of the population in some areas of the Roman Empire. The empire had become vulnerable to such diseases, not at least due to severe climate change in the Roman Transition Period. Harper illustrates how the climate variability of Late Antiquity is intimately connected with epidemics. For example, drought reduces crop yields, cooler temperatures reduce the growing season, and flooding recorded in river sediments indicate episodes of extreme rain. By undermining the grain-based economy and leading to food shortage, such climate events have the potential to trigger epidemics. Harper is a co-author of one review paper [21] in the citation network figure, and has also published a more general paper on climate change and the course of global history [4].

We did not search for publications on paleoclimatic data related to Late Holocene outside the context of the Roman Empire or Late Antiquity, respectively, and therefore presumably missed some relevant literature. Also, the corresponding search terms sometimes do not appear in the titles or abstracts, because the authors mention the relevance of their results for the time period of the Roman Empire only in the full text.

At the risk of oversimplifying, we summarized the 85 key papers mentioned above, which presented paleoclimatic data from various sites of the Roman Empire, as follows:

1. The climate archives revealed the existence of both the Roman and the Medieval Warm Period (Roman and Medieval Climate Optimum) with warmer conditions, separated by the Dark Age Cold Period (Migration Period Pessimum) with prolonged cooling;

2. Lake sediment chronologies, pollen analysis, and multi-proxy data indicate the Iberian-Roman Humid Period, followed by a progressive arid phase since AD 400-450;

3. Speleothem records, stalagmites, and lake sediments indicate dryer conditions in Croatia, Greece, and Israel since about AD 350-500, and a late Roman drought in Anatolia and Levant between $\mathrm{AD} 350$ and $\mathrm{AD} 450$ (and wetter conditions later);

4. Reconstruction of local growing-season temperatures based on stable carbon isotope time-series of cellulose indicates a cold and presumably wet phase between the 4th and 7th century in Germany (Eifel);

5. Climate change in the period of Late Antiquity correlates with documented long-term shifts of some major climate mechanisms, in particular NAO.

The potential of the geosciences and paleoclimatology is, by far, not outbid. For example, Passchier and his coworkers at the University of Mainz (Germany) found out that Roman aqueducts could offer a unique look at how the climate changed on many sides of the Mediterranean region [70,71]. Over time, the rushing water coming from limestone cave springs deposited thick layers of calcite (calcium carbonate) on the channel walls. Similar to cave records, this sinter material has recorded environmental changes throughout the time of operation of the aqueducts. In contrast to cave formations, annual deposits in aqueducts can be one centimeter thick, thereby providing a more highly resolved look into past climate. Measuring the concentration of Oxygen- 18 via geochemical analysis informs about a colder or warmer environment at a specific point in time, provided that the exact age of the layers can be determined (e.g., via radioactive dating). Using the calcium incrustations of Roman aqueducts as climate archives has been suggested already in 1971 [72]. This paper has been detected by the WoS search query III, whereas the basic paper by Passhier [70] is included in the publication set of 85 papers. 
There exist some further interesting papers published as book chapters or conference proceedings, which are either not covered by the WoS or not covered by our search query. For example, a paper entitled "Megadroughts, ENSO, and the Invasion of Late-Roman Europe by the Huns and Avars" [73] is not a WoS database record. However, it appears as cited reference within our publication set and cites itself the underlying research articles [74,75] (see below). Another paper strongly related to the paper on megadroughts in Central Asia [73] and entitled "Migrations of early nomads of the Eurasian steppe in a context of climatic changes" [76] is covered by the WoS, but was not found by our search query.

Such papers can only be detected through searching based on an appropriate search query or through screening the cited references within our publication set. We have carefully inspected the references cited within the 85 papers of our final publication set, and have retrieved additional literature, particularly with regard to early publications (e.g., [77]), and concerning indirect climatic forcing through drought events in Central Asia (e.g., [73]). Since the scientific discourse has just started to switch to the natural sciences, the relevant publications are too recent and cannot be detected based on the number of citations.

In accordance with the prevailing view of the scholars at his time, Saunders questioned in his article "The debate on the fall of Rome" that climate change had played a significant role in the fall of Rome [77]. The attempt by Huntington [12] seems dubious to him: "I have always thought it not a little far-fetched to try to explain the fall of Rome by measuring the girth of redwood trees in California" (p. 8). With regard to indirect climatic forcing, he wrote: "Desiccation in Central Asia may possibly account for the arrival of the Huns in Europe at the end of the fourth century, but I see no way of proving it" (p. 8). Meanwhile, this has changed (see below). According to Storey [18], John Nichols began to focus less on the effect inside the empire as opposed to the climatic conditions outside. "A changing and less benevolent climate may have been a factor in driving the northern barbarians to enter the Roman Empire" [78] (p. 437).

The Eurasian steppe stretches from the plains of Hungary to Eastern Mongolia. Its climate is too dry to support trees and too moist to form a desert. The Juniper tree-ring chronology from Dulan-Wulan on the Tibetan plateau discussed by Cook [73] and based on previous work [74,75] revealed three periods of intense, multi-decadal drought, the first beginning around AD 340 (at about the time of the first migration of the Huns) and lasting for almost forty years in Central Asia (one of the worst in 2000 years). The second major drought occurred in the middle of the 5th century AD, at around the time of the second invasion of the Huns. The third drought period is centered around AD 550, at the time of the invasion of the Avars of Late-Roman Eastern Europe. Above-average wetness before the second and third drought period may have allowed the invaders to build up the capacity for invasion. ENSO is a candidate as a climate system cause, because long-range ENSO forcing of the climate influences the precipitation in Central Asia. NAO is another candidate: when NAO is positive, the westerly jet stream moves north and Central Asia becomes more arid; but when NAO is negative, the jet stream moves toward the equator and more rains reach the steppe.

The in-situ tree-ring evidence is convincing; however, the links to ENSO and NAO are highly speculative. Remote teleconnections between different areas around the globe are difficult to find, even when using very recent data sets. Teleconnections are usually used for seasonal outlooks, but not for extended decadal or multi-decadal climate phenomena, such as long droughts. Extrapolating current weak teleconnections to determine past climate should be used with caution. In his paper on the Hunnic migrations, Cook [73] claims he saw the Huns moving from Mongolia, but specialists now understand that the Huns who crossed into the Roman Empire were not far east of the Volga River.

The Dulan-Wulan tree-ring data clearly confirm speculations about a climatic factor in the migration of the Huns. The Huns, for their part, induced the movement of the Goths from north of the Black Sea across the Danube into the Roman Empire, which is widely seen as the origin of the Migration Period. Possibly, the nomadic Huns tried to escape from the drought region in Central Asia and simply moved towards areas with more grass for their cattle. "The Huns were armed climate refugees on horseback" [13] (p. 192). Their basic weapon was a composite reflex bow, which increased 
their military clout substantially [7]. According to the Roman historian Ammianus, "You would not hesitate to call them the most terrible of all warriors" (cited in [13], p. 193). The Huns are one brick in the building block of the far-reaching impact of a changing climate. "We need not go in for monocausal explanations. The coming of the Huns did not, by itself, spell the doom of the western empire" [13] (p. 163).

More recent works on nomads and climate by Di Cosmo et al. $[79,80]$ modify and relativize the connection between climate and the migration of nomads: With regard to the collapse of the Eastern Turk Empire (ETE, ca. AD 584-630), Di Cosmo argues that reduction in vegetation growth and increased livestock mortality associated with a climatic shift should be evaluated within a comprehensive analysis of political relations [79]. Regarding the re-evaluation of the history of the Uyghur Empire (AD 744-840) in connection with newly available paleoclimate data, Di Cosmo states that the assumption of a direct causal link between drought and the stability of nomadic societies is not always justified. A severe drought lasting nearly seven decades did not cause this nomadic empire to collapse or to disintegrate [80].

The periodic migration of Asian nomads can be traced by archeological and written sources. An analysis of lake deposits and loess-soil cross-sections by Bokovenko shows significant changes of the climate, which correlate with their migrations [76]. In his conclusion, Bokovenko states: "The origin of these migrations is not yet clear. They may be caused by political ambitions. But there are no doubts that climatic changes played an essential role by stimulating the move of numerous nomads over great distances" (p. 31). In summary, at around AD 350, the Roman Optimum was over and replaced by the Migration Era Pessimum, which lasted until the beginning of the Medieval Climate Optimum at around AD 800. The drought in Central Asia and the onset of a cooler climate in North-West Eurasia possibly put Germanic tribes, Goths, and Huns on the move straight into the Roman Empire.

\subsection{News Mentions}

The papers of our publication set with more than ten news mentions are: (1) the paper by Luterbacher [32] with 25 news mentions; and (2) the paper by Büntgen [81] with Luterbacher as one of the co-authors, which received 15 news mentions. Based on the expanded number of high-quality proxy records and new statistical reconstruction methods, Luterbacher et al. presented and discussed an annually resolved, spatial reconstruction of the European summer temperature since Roman times. Büntgen et al. used tree-ring chronologies from the Russian Altai and European Alps to reconstruct summer temperatures over the past two millennia, and found a long-lasting cooling period after a series of three volcanic eruptions around AD 550. This coincides with ongoing political turmoil, migration, and pandemics. The accessible news reports dealing with the paper by Luterbacher et al. [32] are focused on the temperature increase within the recent decades against the backdrop of the current global-warming discussion. Many news reports dealing with the tree-ring data presented by Büntgen et al. [81] discuss the connection between the Late Antiquity Little Ice Age and the fall of the Western Roman Empire. Others debate whether climate change can alter the course of history in general or deal with a possible link between climate change and epidemics or food shortage. The analogy with current civil wars and migration presumably provoke public interest. Interested readers may inspect the news articles at https:/ / www.altmetric.com/details/5056795/news and https://www.altmetric.com/details/5108025/news.

\section{Discussion}

The current bibliometric study is based on the literature (accessible via the WoS literature database) dealing with the decline and fall of the Roman Empire and the references cited therein. Due to the poor coverage of books by the WoS, the publication set analyzed here mainly includes research articles written in English, which means that many publications by historians on the fall of Rome are not considered. However, this literature has been used to interpret the bibliometric results. The study shows that, until present, the amount of literature on the fall of Rome in connection with climate 
change and the number of researchers, respectively, is comparatively low; most of the relevant papers appeared more recently. The publications citing the papers of our final publication set primarily discuss paleoclimatic analysis methods and data from larger time periods (e.g., some millennia) with no specific focus on the fall of Rome.

There exists no clear dividing line between the publications studying climate change over the complete timespan of the Late Holocene and those specifically focused on the time period of the Roman Empire and the transition to the Middle Ages. Earlier papers tend to mention only the Roman Warm Period, whereas more recent publications are increasingly dealing with the impact of a shifting climate on the rise and decline of the Roman Empire. Most classic books on the fall of Rome discuss the climate only marginally, if at all. The content analysis of the relevant papers indicates a shift from endogenous to exogenous forces. However, anthropogenically-driven climate change is currently still not seen as a leading force in the fall of Rome [10]. Some historians, however, are convinced that a naturally shifting climate was a major force both for the rise and fall of civilizations (Kyle Harper, Michael McCormick). Many other historians are still reluctant.

A multitude of paleoclimatic data from various sites of the Roman Empire revealed the existence of the Roman Warm Period (Roman Climate Optimum) and the Migration Period Pessimum. For the period, when severe economic, political, and military crises came up, many proxy data reveal a shift away from the stability of the previous centuries: a cooler and dryer climate for the north-western provinces, and a progressive arid phase in the south-eastern and southern provinces. Climatic change seems to have impacted not only on the Roman World itself, but also its peripheral regions and Asia, influencing the course of history in a more indirect way. Recently, some researchers argued that drought in Central Asia and the onset of a cooler climate in North-West Eurasia may have put Germanic tribes, Goths, and Huns on the move into the Roman Empire, provoking the Migration Period—and by this, eventually, the downfall of the Western Roman Empire.

In his book entitled "The Great Warming", Brian Fagan discusses the migration of the Mongols under their leader Ginghis Khan as a result of climatic change in Central Asia [82]. He points out that arid lands, such as steppes and deserts, are extremely sensitive to even tiny variations in rainfall, and act as huge pumps: After rainfall, nomadic people are attracted to its promises of grazing land and water; when dry conditions return, the nomads and their herds are expelled to the margins. Although Fagan has no specific expertise in the history of the Mongols, this scenario can possibly be applied to the migration of the Huns about one millennium prior, resulting in the Migration Period and eventually causing the downfall of the Roman Empire.

The complexity of the environmental, economic, and political interactions on the one hand, and the incompleteness of suitable records and lack of precision in their dating on the other, preclude a simplistic unraveling of the connections and closing answers. A combination of many factors interacting with each other (civil wars, defense against barbarians, the impacts of internal and external climatic pressure, pandemic diseases, and many others mentioned above) is a possible explanation for the scenario of the long-lasting decline and final collapse of the Roman Empire.

However, the various paleoclimatic records indicate distinct fluctuations of the climate during Late Antiquity. We may assume that a more comfortable climate was decisive for the rise of the Roman Empire, and a shifting climate might have been a major triggering factor for weakening the power of Rome. Since a society relies on a fine margin of climate stability, even small climatic changes can have notable effects [10]. Overlooking this is presumably one possible reason for why the potentially decisive role of the climate for the stability of societies has often been underestimated. We do not want to advocate for simple or reductionist theories-we do not know if the fluctuations of the climate were a triggering factor; the data only deliver a possible explanation (which can be explored in future studies).

The effects of the climatic shift at the time of Late Antiquity seem to be more indirect. It was not so much the immediate impact, but the consequences that caused political and social change and eventually the downfall. It is still difficult to assert, how far climate change affected the struggle 
of the later Roman Empire. "But climate change was always an exogenous factor, a true wild card, transcending all other rules of the game ... The rise and fall of Rome remind us that the story of human civilization is, through and through, an environmental drama" [13] (p. 15). Harper's work is likely to re-ignite the debate about the role of environmental change in the fall of Rome.

Against the backdrop of the current amount of research activity and the public discussion around global warming, scholars are in danger of being focused too much on "climate downturns", and of over-explaining and simplifying the role of the climate for the end of Rome. However, climate research might deliver important data for a better understanding, which can be used and interpreted by historians. We do not argue that climate change was the main cause for the fall of Rome. However, we summarize the literature analyzed here by saying that climate change has come into play. Our bibliometric approach: (1) quantifies the amount and time evolution of the relevant literature; (2) presents the most active authors and their co-authorship; and (3) also presents the linkage of the relevant papers within their citation network. Literature overviews published by experts in specific fields are in danger of being subjective based on their own background and specific interests. A bibliometric approach can provide a more unbiased view of the scientific discussion.

What are the limitations of this bibliometric analysis? (1) As already mentioned, in the fields of archeology and history, a large portion of literature is published as books or book chapters. However, books are scarcely covered by literature databases such as the WoS. Since they appear as cited references within research articles, some relevant books and book reviews have been included in the analysis. (2) Our selection of the 10 key papers is somewhat arbitrary, but they are only the starting point for a more detailed search (see Figure 1). (3) The publication set analyzed here ( $\mathrm{n}=85$ papers) is comparatively small, but the papers already deliver a consistent picture of the discussion initiated by the paleoclimatic data available at present.

\section{Conclusions}

The rapidly evolving climate change research (against the backdrop of the danger of global warming), and the increasing availability of paleoclimatic data, enabled scholars to better analyze the role of anthropogenic and natural climatic shifts for the course of history in Late Antiquity. In recent years, the number of records from different locations, the toolbox of suitable analytic methods, and the precision of dating all evolved rapidly. However, until now, the impact of the past climate on the course of history has been discussed primarily by climatologists. Therefore, historians sometimes recommend that more experts from their discipline are brought on board.

The use of the climate in the history of Rome seems to be different in work conducted by historians and archeologists than in work conducted by climatologists. Historians study the evolution of societies as an interaction of many components (culture, economy, environment, military power, etc.) within a sophisticated network. Their interpretations and conclusions are based on archeological artefacts and written records. In contrast, climate scientists are solely focused on climatic shifts documented by paleoclimatic data. They correlate climatic events, such as periods of drought, with historical events, such as the migration of nomads, and establish hypotheses with climate change as an indication for having caused or influenced historical processes. Historians underestimate the explanatory power and the future perspective of paleoclimatic data; climatologists discuss historical events, which they cannot study with due care.

Many studies on the decline of Rome lack the inevitable collaboration between disciplines: archeology, history, and climatology. Different research cultures and lack of insight in the complementary discipline hamper better collaboration. Climate researchers mainly cite other climate researchers (see Figure 4a), and historians seem to primarily cite other historians. Typically, historians are not trained climate scientists, and climate researchers analyzing the past climate are not trained historians. Climatologists not trained in ancient history or in textual analysis cannot properly interpret the historical context of the data they produce, and historians cannot be trusted with paleoclimate data. Better communication between archeologists, historians, and natural scientists has already been 
suggested $[21,34]$, and seems to be highly promising for answering one of the most classic historical questions. We encourage scholars studying the history of Rome to intensify collaborations across disciplinary boundaries.

The Roman Empire is not the only civilization that possibly came to fall in connection with climatic change. The Akkadian empire in Mesopotamia, the Old Kingdom civilization of Egypt, the Harappan civilization of the Indus valley, the Anasazi in North America, the Maya civilization in Central America, as well as the Moche and the Tiwanaku civilization in South America, collapsed in periods of severe drought [82-84]. An extensive bibliometric analysis of the complete body of literature dealing with the impact of climate change or climate variability on the rise and fall of ancient civilizations would be most interesting.

Many scholars do not believe that climate change was crucial, let alone a driving force, of each of these "collapses". The answers to some basic questions should act as starting points for studying these collapses: How are we defining "collapse"? Did these "collapses" look anything like the Roman "collapse"? Other aspects also still requiring attention are:

- Vulnerability, or sensitivity, to climate change is not equal, different societies were better able to withstand certain climate changes than others;

- The possible impact of climate change on other factors decisive for the demise of societies, like food production and livestock pasture;

- A better understanding of the casual chain from climate shift to history;

- The re-interpretation of written records with regard to climatic shifts, as documented by paleoclimatic records.

If we want to draw lessons from the collapse of the Western Roman Empire, then this is one: Complex societies are very fragile because they rely on a sophisticated network of production and distribution, depending (largely) on fine margins of climate stability [8,10]. Climate research tells us that even small climatic changes can have notable effects. So far, it has been shown that climate change has the potential to be an important factor for the evolution of civilizations and their downfall. However, climate is always one of many factors interacting with each other. In view of the current situation on global warming, humans would be wise to consider this. At the same time, more attention should be paid to societal resilience to environmental change. After all, the Eastern Roman Empire, which was also a complex state, managed, for a variety of reasons, to survive late antique environmental change, not to mention long wars with Sassanid Persia and the Arab conquests [85,86]. Lessons are to be learned from resilient past societies too.

Author Contributions: W.M. conceived and performed the analysis; R.H. and L.B. contributed to the bibliometric methods; W.M. prepared the initial draft manuscript; R.H. and L.B. contributed to and commented on the final manuscript.

Funding: This research received no external funding. The APC was funded by the Max Planck Digital Library (MPDL).

Acknowledgments: The authors thank the anonymous reviewers for their valuable comments and suggestions. The news data were taken from a data set retrieved from Altmetric on 2 October 2017, which is stored in a local database and maintained by the Max Planck Institute for Solid State Research (Stuttgart).

Conflicts of Interest: The authors declare no conflict of interest.

\section{Appendix A}

WoS Search Queries (date of searching: 1 April 2018). 
Search Query I

\# 3257

\# 2

1123

\# 1

Search Query II

\# $4 \quad 46$

$\# 3 \quad 25$

\# $2 \quad 15$

$\# 1 \quad 17$
TITLE: (( (breakdown OR collapse OR decline OR demise OR doom OR end OR downfall OR fall OR fate) SAME (rome OR roman OR romans OR "late antiquity") NOT republic))

Refined by: [excluding] RESEARCH AREAS: (MUSIC OR LITERATURE OR FILM RADIO TELEVISION OR LINGUISTICS OR ART OR THEATER) AND DOCUMENT TYPES: (ARTICLE OR PROCEEDINGS PAPER OR REVIEW) Indexes=SCI-EXPANDED, SSCI, A\&HCI, CPCI-S, CPCI-SSH, BKCI-S, BKCI-SSH, ESCI, CCR-EXPANDED, IC

Timespan=All years

TITLE: (( breakdown OR collapse OR decline OR demise OR doom OR end OR downfall OR fall OR fate) SAME (rome OR roman OR romans OR "late antiquity") NOT republic))

Refined by: [excluding] RESEARCH AREAS: (MUSIC OR LITERATURE OR FILM RADIO TELEVISION OR LINGUISTICS OR ART OR THEATER) Indexes=SCI-EXPANDED, SSCI, A\&HCI, CPCI-S, CPCI-SSH, BKCI-S, BKCI-SSH, ESCI, CCR-EXPANDED, IC

Timespan=All years

TITLE: (((breakdown OR collapse OR decline OR demise OR doom OR end OR downfall OR fall OR fate) SAME (rome OR roman OR romans OR “late antiquity") NOT republic))

Indexes=SCI-EXPANDED, SSCI, A\&HCI, CPCI-S, CPCI-SSH, BKCI-S, BKCI-SSH, ESCI, CCR-EXPANDED, IC

Timespan=All years

\section{\#3 OR \#2 OR \#1}

Indexes=SCI-EXPANDED, SSCI, A\&HCI, CPCI-S, CPCI-SSH, BKCI-S, BKCI-SSH, ESCI, CCR-EXPANDED, IC

Timespan=All years

TOPIC: ((breakdown OR collapse OR decline OR demise OR doom OR end OR downfall OR fall OR fate) NEAR/5 (rome OR roman OR romans OR “late antiquity")) AND TITLE: (climat* OR environment*) Indexes=SCI-EXPANDED, SSCI, A\&HCI, CPCI-S, CPCI-SSH, BKCI-S, BKCI-SSH, ESCI, CCR-EXPANDED, IC

Timespan=All years

TITLE: ((breakdown OR collapse OR decline OR demise OR doom OR end OR downfall OR fall OR fate) SAME (rome OR roman OR romans OR "late antiquity")) AND TOPIC: (climat* OR environment ${ }^{*}$ ) Indexes=SCI-EXPANDED, SSCI, A\&HCI, CPCI-S, CPCI-SSH, BKCI-S, BKCI-SSH, ESCI, CCR-EXPANDED, IC

Timespan=All years

TITLE: ((rome OR roman OR romans OR "late antiquity")

SAME ("climat* chang*"))

Indexes=SCI-EXPANDED, SSCI, A\&HCI, CPCI-S, CPCI-SSH,

BKCI-S, BKCI-SSH, ESCI, CCR-EXPANDED, IC

Timespan=All years 


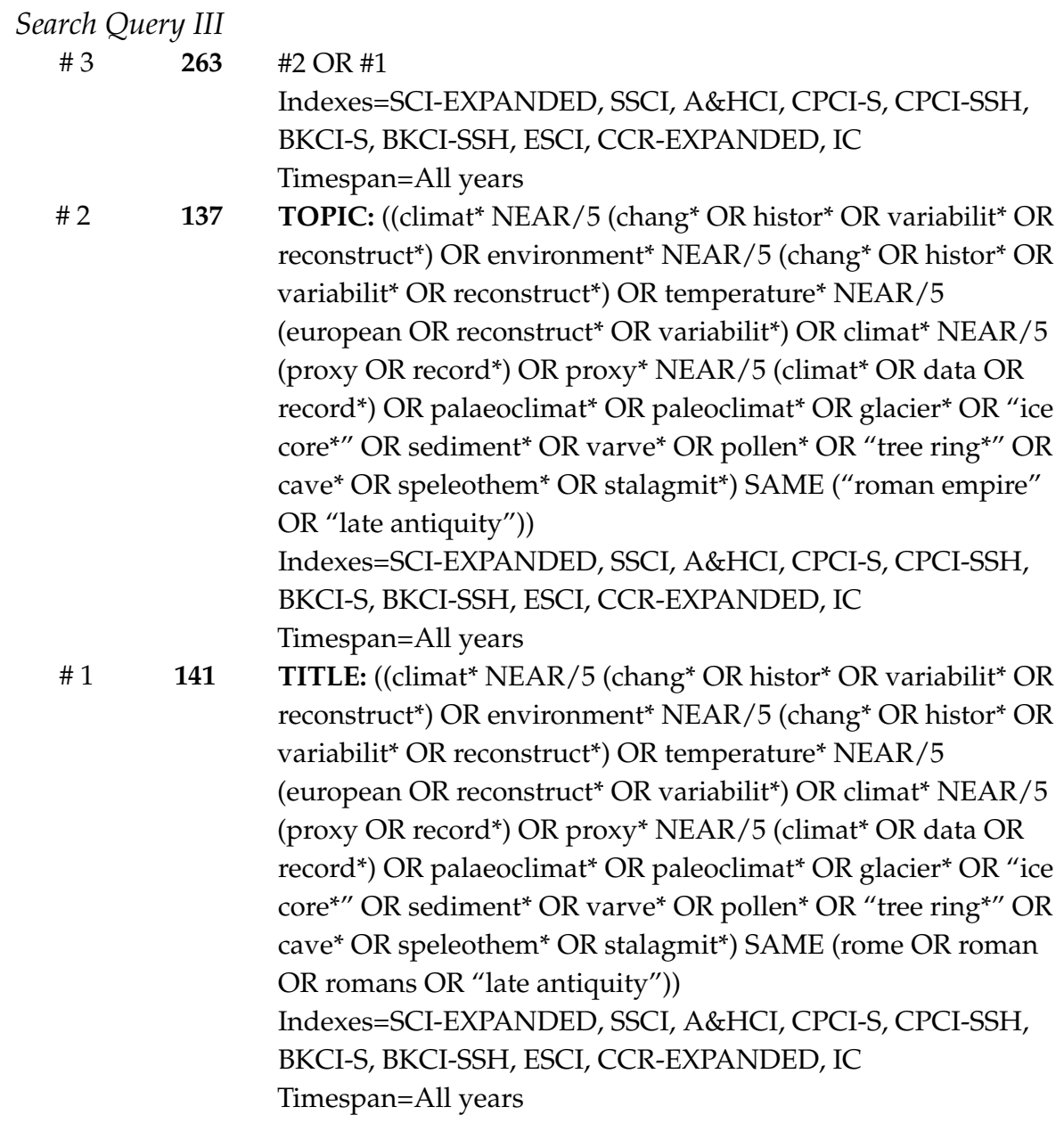

\section{Appendix B}

Listing of the 85 papers of the publication set analyzed in this study.

1. Masi, A.; Francke, A.; Pepe, C.; Thienemann, M.; Wagner, B.; Sadori, L.: Vegetation history and paleoclimate at Lake Dojran (FYROM/Greece) during the Late Glacial and Holocene. Climate of the Past 14(3), 351-367 (2018). DOI: 10.5194/cp-14-351-2018

2. Helama, S.; Arppe, L.; Uusitalo, J.; Holopainen, J.; Makela, H.M.; Makinen, H.; Mielikainen, K.; Nojd, P.; Sutinen, R.; Taavitsainen, J.P.; Timonen, M.; Oinonen, M.: Volcanic dust veils from sixth century tree-ring isotopes linked to reduced irradiance, primary production and human health. Scientific Reports 8, article number 1339 (2018). DOI: 10.1038/s41598-018-19760-w

3. Moravcsik, A.: The fate of Rome: climate, disease, and the end of an empire. Foreign Affairs 97(1), 160-160 (2018).

4. Psomiadis, D.; Dotsika, E.; Albanakis, K.; Ghaleb, B.; Hillaire-Marcel, C.: Speleothem record of climatic changes in the northern Aegean region (Greece) from the Bronze Age to the collapse of the Roman Empire. Palaeogeography Palaeoclimatology Palaeoecology 489, 272-283 (2018). DOI: $10.1016 /$ j.palaeo.2017.10.021

5. Palmisano, A.; Bevan, A.; Shennan, S.: Comparing archaeological proxies for long-term population patterns: An example from central Italy. Journal of Archaeological Science 87, 59-72 (2017). DOI: 10.1016/j.jas.2017.10.001 
6. Decker, M.J.: Approaches to the environmental history of Late Antiquity, part II: climate change and the end of the Roman Empire. History Compass 15(10), article number e12425 (2017). DOI: $10.1111 /$ hic 3.12425

7. Decker, M.J.: Approaches to the environmental history of Late Antiquity, part 1: the rise of Islam. History Compass 15(10), article number e12407 (2017). DOI: 10.1111/hic3.12407

8. Kearns, C.: Mediterranean archeology and environmental histories in the spotlight of the Anthropocene. History Compass 15(10), article number: e12371 (2017). DOI: 10.1111/hic3.12371

9. Defive, E.; Berger, J.F.; Poiraud, A.; Barra, A.; Bouvard, E.; Virmoux, C.; Voldoire, O.; Garreau, A.; Miras, Y.; Beauger, A.; Cabanis, M.; Gunnell, Y.; Braucher, R.; Dendievel, A.M.; Nomade, S.; Delvigne, V.; Lafarge, A.; Liabeuf, R.; Guillou, H.; Raynal, J.P.: The three last millenia history of the Holocene hydro-sedimentary flows in the upstream Loire river basin (Massife Central, France): contribution of a cumulative probability density function (CPDF) analysis and regional correlations. Quaternaire 28(3), 373-388 (2017).

10. Allcock, S.L.: Long-term socio-environmental dynamics and adaptive cycles in Cappadocia, Turkey during the Holocene. Quaternary International 446, 66-82 (2017). DOI: 10.1016/j.quaint.2017.06.065

11. Henkner, J.; Ahlrichs, J.J.; Downey, S.; Fuchs, M.; James, B.R.; Knopf, T.; Scholten, T.; Teuber, S.; Kuhn, P.: Archaeopedology and chronostratigraphy of colluvial deposits as a proxy for regional land use history (Baar, southwest Germany). Catena 155, 93-113 (2017). DOI: 10.1016/j.catena2017.03.005

12. Franke, J.G.; Donner, R.V.: Dynamical anomalies in terrestrial proxies of North Atlantic climate variability during the last $2 \mathrm{ka}$. Climate Change 143(1-2), 87-100 (2017). DOI: 10.1007/s10584-017-1979-z

13. van Dinter, M.; Cohen, K.M.; Hoek, W.Z.; Stouthamer, E.; Jansma, E.; Middelkoop, H.: Late Holocene lowland fluvial archives and geoarchaeology: Utrecht's case study of Rhine river abandonment under Roman and medieval settlement. Quaternary Science Reviews 166(SI), 227-265 (2017). DOI: 10.1016/j.quascirev.2016.12.003

14. Drake, B.L.: Changes in North Atlantic Oscillation drove population migrations and the collapse of the Western Roman Empire. Scientific Reports 7, article number: 1227 (2017). DOI: $10.1038 / \mathrm{s} 41598-017-01289-\mathrm{z}$

15. Fuks, D.; Ackermann, O.; Ayalon, A.; Bar-Matthews, M.; Bar-Oz, G.; Levi, Y.; Maeir, A.M.; Weiss, E.; Zilberman, T.; Safrai, Z.: Dust clouds, climate change and coins: consiliences of palaeoclimate and economy in the Late Antique southern Levant. Levant 49(2), 205-223 (2017). DOI: $10.1080 / 00758914.2017 .1379181$

16. Storey, R.; Storey, G.R.: Rome and the Classic Maya: comparing the slow collapse of civilizations. Routledge, Oxford (UK), 1st ed., 280 p. (2017). ISBN: 978-1-62958-458-4; 978-1-315-30941-5; 978-1-62958-457-7

17. Oumghar, S.: The climate of North Africa in the Roman era: new approaches. Hesperis-Tamuda 52(1, SI), 49-81 (2017).

18. Bravard, J.P.; Mostafa, A.; Garcier, R.; Tallet, G.; Ballet, P.; Bolo, A.; Chevalier, Y.; Tronchere, H.: Rise and fall of an Egyptian oasis: artesian flow, irrigation soils, and historical agricultural development in El-Deir, Kharga Depression, western desert of Egypt. Geoarchaeology-An International Journal 31(6), 467-486 (2016). DOI: 10.1002/gea.21566

19. Passchier, C.; Surmelihindi, G.; Spotl, C.; Mertz-Kraus, R.; Scholz, D.: Carbonate deposits from the ancient aqueduct of Beziers, France - A high-resolution palaeoenvironmental archive for the Roman Empire. Palaeogeography Palaeoclimatology Palaeoecology 461, 328-340 (2016). DOI: $10.1016 /$ j.palaeo.2016.08.022 
20. Sanchez-Lopez, G.; Hernandez, A.; Pla-Rabes, S.; Trigo, R.M.; Toro, M.; Granados, I.; Saez, A.; Masque, P.; Pueyo, J.J.; Rubio-Ingles, M.J.; Giralt, S.: Climate reconstruction for the last two millennia in central Iberia: the role of East Atlantic (EA), North Atlantic Oscillation (NAO) and their interplay over the Iberian Peninsula. Quaternary Science Reviews 149, 135-150 (2016). DOI: $10.1016 /$ j.quascirev.2016.07.021

21. Lopez-Costas, O.; Muldner, G.: Fringes of the empire: diet and cultural change at the Roman to post-Roman transition in NW Iberia. American Journal of Physical Anthropology 161(1), 141-154 (2016). DOI: 10.1002/ajpa.23016

22. Sizling, A.L.; Pokorny, P.; Jurickova, L.; Horackova, J.; Abraham, V.; Sizlingova, E.; Lozek, V.; Tjorve, E.; Tjorve, K.M.C.; Kunin, W.: Can people change the ecological rules that appear general across space? Global Ecology and Biogeography 25(9), 1072-1084 (2016). DOI: 10.1111/geb.12467

23. Elliott, C.P.: The Antonine Plague, climate change and local violence in Roman Egypt. Past and Present 231, 3-31 (2016. DOI: 10.1093/pastj/gtv058

24. Izdebski, A.; Holmgren, K.; Weiberg, E.; Stocker, S.R.; Buentgen, U.; Florenzano, A.; Gogou, A.; Leroy, S.A.G.; Luterbacher, J.; Martrat, B.; Masi, A.; Mercuri, A.M.; Montagna, P.; Sadori, L.; Schneider, A.; Sicre, M.A.; Triantaphyllou, M.; Xoplaki, E.: Realising consilience: how better communication between archaeologists, historians and natural scientists can transform the study of past climate change in the Mediterranean. Quaternary Science Reviews 136(SI), 5-22 (2016). DOI: $10.1016 /$ j.quascirev.2015.10.038

25. Mazzini, I.; Gliozzi, E.; Galaty, M.; Bejko, L.; Sadori, L.; Soulie-Marsche, I.; Koci, R.; van Welden, A.; Bushati, S.: Holocene evolution of Lake Shkodra: multidisciplinary evidence for diachronic landscape change in northern Albania. Quaternary Science Reviews 136(SI), 85-95 (2016). DOI: 10.1016/j.quascirev.2016.01.006

26. Morellon, M.; Anselmetti, F.S.; Ariztegui, D.; Brushulli, B.; Sinopoli, G.; Wagner, B.; Sadori, L.; Gilli, A.; Pambuku, A.: Human-climate interactions in the central Mediterranean region during the last millennia: the laminated record of Lake Butrint (Albania). Quaternary Science Reviews 136(SI), 134-152 (2016). DOI: 10.1016/j.quascirev.2015.10.043

27. Izdebski, A; Pickett, J.; Roberts, N.; Waliszewski, T.: The environmental, archaeological and historical evidence for regional climatic changes and their societal impacts in the eastern Mediterranean in Late Antiquity. Quaternary Science Reviews 136(SI), 189-208 (2016). DOI: $10.1016 /$ j.quascirev.2015.07.022

28. Xoplaki, E.; Fleitmann, D.; Luterbacher, J.; Wagner, S.; Haldon, J.F.; Zorita, E.; Telelis, I.; Toreti, A.; Izdebski, A.: The medieval climate anomaly and Byzantium: a review of the evidence on climatic fluctuations, economic performance and societal change. Quaternary Science Reviews 136(SI), 229-252 (2016). DOI: 10.1016/j.quascirev.2015.10.004

29. Ollive, V.; Ernst, T.; Franck, J.; Meyer, N.; Thomashausen, L.; Viller, S.: The agricultural erosion in a small catchment in Lorraine since 2000 years: geoarchaeology along the TGV-Est line. Quaternaire 27(1), 27-37 (2016).

30. Harper, K.: The environmental fall of the Roman Empire. Daedalus 145(2), 101-111 (2016). DOI: 10.1162/DAED_a_00380

31. Buentgen, U.; Myglan, V.S.; Ljungqvist, F.C.; McCormick, M.; Di Cosmo, N.; Sigl, M.; Jungclaus, J.; Wagner, S.; Krusic, P.J.; Esper, J.; Kaplan, J.O.; de Vaan, M.A.C.; Luterbacher, J.; Wacker, L.; Tegel, W.; Kirdyanov, A.V.: Cooling and societal change during the late Antique little ice age from 536 to around 660 AD. Nature Geoscience 9(3), 231-237 (2016). DOI: 10.1038/NGEO2652 
32. Luterbacher, J.; Werner, J.P.; Smerdon, J.E.; Fernandez-Donado, L.; Gonzalez-Rouco, F.J.; Barriopedro, D.; Ljungqvist, F.C.; Buentgen, U.; Zorita, E.; Wagner, S.; Esper, J.; McCarroll, D.; Toreti, A.; Frank, D.; Jungclaus, J.H.; Barriendos, M.; Bertolin, C.; Bothe, O.; Brazdil, R.; Camuffo, D.; Dobrovolny, P.; Gagen, M.; Garica-Bustamante, E.; Ge, Q.; Gomez-Navarro, J.J.; Guiot, J.; Hao, Z.; Hegerl, G.C.; Holmgren, K.; Klimenko, V.V.; Martin-Chivelet, J.; Pfister, C.; Roberts, N.; Schindler, A.; Schurer, A.; Solomina, O.; von Gunten, L.; Wahl, E.; Wanner, H.; Wetter, O.; Xoplaki, E.; Yuan, N.; Zanchettin, D.; Zhang, H.; Zerefos, C.: European summer temperatures since Roman times. Environmental Research Letters 11(2), article number: 024001 (2016). DOI: 10.1088/1748-9326/11/2/024001

33. Cisneros, M.; Cacho, I.; Frigola, J.; Canals, M.; Masque, P.; Martrat, B.; Casado, M.; Grimalt, J.O.; Pena, L.D.; Margaritelli, G.; Lirer, F.: Sea surface temperature variability in the central-western Mediterranean Sea during the last 2700 years: a multi-proxy and multi-record approach. Climate of the Past 12(4), 849-869 (2016). DOI: 10.5194/cp-12-849-2016

34. Degeai, J.P.; Devillers, B.; Dezileau, L.; Oueslati, H.; Bony, G.: Major storm periods and climate forcing in the western Mediterranean during the Late Holocene. Quaternary Science Reviews 129, 37-56 (2015). DOI: 10.1016/j.quascirev.2015.10.009

35. Etienne, D.; Destas, M.; Lyautey, E.; Marti, R.; Ruffaldi, P.; Georges-Leroy, M.; Dambrine, E.; Topp, E.: Two thousand-year reconstruction of livestock production intensity in France using sediment-archived fecal Bacteroidales and source-specific mitochondrial markers. Holocene 25(9), 1384-1393 (2015). DOI: $10.1177 / 0959683615585836$

36. Cheddadi, R.; Nourelbait, M.; Bouaissa, O.; Tabel, J.; Rhoujjati, A.; Lopez-Saez, J.A.; Alba-Sanchez, F.; Khater, C.; Ballouche, A.; Dezileau, L.; Lamb, H.: A history of human impact on Moroccan mountain landscapes. African Archaeological Review 32(2, SI), 233-248 (2015). DOI: 10.1007/s10437-015-9186-7

37. Mensing, S.A.; Tunno, I.; Sagnotti, L.; Florindo, F.; Noble, P.; Archer, C.; Zimmerman, S.; Pavon-Carrasco, F.J.; Cifani, G.; Passigli, S.; Piovesan, G.: 2700 years of Mediterranean environmental change in central Italy: a synthesis of sedimentary and cultural records to interpret past impacts of climate on society. Quaternary Science Reviews 116, 72-94 (2015). DOI: 10.1016/j.quascirev.2015.03.022

38. Miras, Y.; Beauger, A.; Lavrieux, M.; Berthon, V.; Serieyssol, K.; Andrieu-Ponel, V.; Ledger, P.M.: Tracking long-term human impacts on landscape, vegetal biodiversity and water quality in the Lake Aydat catchment (Auvergne, France) using pollen, non-pollen palynomorphs and diatom assemblages. Palaeogeography Palaeoclimatology Palaeoecology 424, 76-90 (2015). DOI: $10.1016 /$ j.palaeo.2015.02.016

39. Felja, I.; Fontana, A.; Furlani, S.; Bajraktarevic, Z.; Paradzik, A.; Topalovic, E.; Rossato, S.; Cosovic, V.; Juracic, M.: Environmental changes in the lower Mirna River valley (Istria, Croatia) during the middle and late Holocene. Geologia Croatica 68(3), 209-224 (2015). DOI: 10.4154/gc.2015.16

40. Esper, J.; Duthorn, E.; Krusic, P.J.; Timonen, M.; Buentgen, U.: Northern European summer temperature variations over the common era from integrated tree-ring density records. Journal of Quaternary Science 29(5), 487-494 (2014). DOI: 10.1002/jqs.2726

41. Bruno, L.; Amorosi, A.; Curina, R.; Severi, P.; Bitelli, R.: Human-landscape interactions in the Bologna area (northern Italy) during the mid-late Holocene, with focus on the Roman Period. Holocene 23(11), 1560-1571 (2013). DOI: 10.1177/0959683613499054

42. Grauel, A.L.; Goudeau, M.L.S; de Lange, G.J.; Bernasconi, S.M.: Climate of the past 2500 years in the Gulf of Taranto, central Mediterranean Sea: a high-resolution climate reconstruction based on delta O-18 and delta C-13 of Globigerinoides ruber (white). Holocene 23(10), 1440-1446 (2013). DOI: $10.1177 / 0959683613493937$ 
43. Craft, S.: An environmental history of ancient Greece and Rome. Classical Review 63(2), 483-485 (2013). DOI: 10.1017/S0009840X13000826

44. Romano, P.; Di Vito, M.A.; Giampaola, D.; Cinque, A.; Bartoli, C.; Boenzi, G.; Detta, K.; Di Marco, M.; Giglio, M.; Iodice, S.; Liuzza, V.; Ruello, M.R.; di Cola, C.S.: Intersection of exogenous, endogenous and anthropogenic factors in the Holocene landscape: a study of the Naples coastline during the last 6000 years. Quaternary International 303, 107-119 (2013). DOI: 10.1016/j.quaint.2013.03.031

45. Maselli, V.; Trincardi, F.: Man made deltas. Scientific Reports 3, article number: 1926 (2013). DOI: $10.1038 /$ srep01926

46. Bakker, J.; Paulissen, E.; Kaniewski, D.; Poblome, J.; De Laet, V.; Verstraeten, G.; Waelkens, M.: Climate, people, fire and vegetation: new insights into vegetation dynamics in the eastern Mediterranean since the 1st century AD. Climate of the Past 9(1), 57-87 (2013). DOI: $10.5194 /$ cp-9-57-2013

47. Bruins, H.J.: Ancient desert agriculture in the Negev and climate-zone boundary changes during average, wet and drought years. Journal of Arid Environments 86(SI), 28-42 (2012). DOI: $10.1016 /$ j.jaridenv.2012.01.015

48. Sapart, C.J.; Monteil, G.; Prokopiou, M.; van de Wal, R.S.W.; Kaplan, J.O.; Sperlich, P.; Krumhardt, K.M.; van der Veen, C.; Houweling, S.; Krol, M.C.; Blunier, T.; Sowers, T.; Martinerie, P.; Witrant, E.; Dahl-Jensen, D.; Rockmann, T.: Natural and anthropogenic variations in methane sources during the past two millennia. Nature 490(7418), 85-88 (2012). DOI: 10.1038/nature11461

49. McCormick, M.; Buentgen, U.; Cane, M.A.; Cook, E.R.; Harper, K.; Huybers, P.; Litt, T.; Manning, S.W.; Mayewski, P.A.; More, A.F.M.; Nicolussi, K.; Tegel, W.: Climate change during and after the Roman Empire: reconstructing the past from scientific and historical evidence. Journal of Interdisciplinary History 43(2), 169-220 (2012). DOI: 10.1162/JINH_a_00379

50. Rudzka, D.; Mcdermott, F.; Suric, M.: A late Holocene climate record in stalagmites from Modric Cave (Croatia). Journal of Quaternary Science 27(6), 585-596 (2012). DOI: 10.1002/jqs.2550

51. Wang, T.; Surge, D.; Mithen, S.: Seasonal temperature variability of the Neoglacial (3300-2500 BP) and Roman Warm Period (2500-1600 BP) reconstructed from oxygen isotope ratios of limpet shells (Patella vulgata), Northwest Scotland. Palaeogeography Palaeoclimatology Palaeoecology 317, 104-113 (2012). DOI: 10.1016/j.palaeo.2011.12.016

52. Curras, A.; Zamora, L.; Reed, J.M.; Garcia-Soto, E.; Ferrero, S.; Armengol, X; Mezquita-Joanes, F.; Marques, M.A.; Riera, S.; Julia, R.: Climate change and human impact in central Spain during Roman times: high-resolution multi-proxy analysis of a Tufa Lake record (Somolinos, $1280 \mathrm{~m}$ asl). Catena 89(1), 31-53 (2012). DOI: 10.1016/j.catena.2011.09.009

53. Dermody, B.J.; de Boer, H.J.; Bierkens, M.F.P.; Weber, S.L.; Wassen, M.J.; Dekker, S.C.: A seesaw in Mediterranean precipitation during the Roman Period linked to millennial-scale changes in the North Atlantic. Climate of the Past 8(2), 637-651 (2012). DOI: 10.5194/cp-8-637-2012

54. Chen, L.; Zonneveld, K.A.F.; Versteegh, G.J.M.: Short term climate variability during “Roman Classical Period" in the eastern Mediterranean. Quaternary Science Reviews 30(27-28), 3880-3891 (2011). DOI: 10.1016/j.quascirev.2011.09.024

55. Ghilardi, M.; Boraik, M.: Reconstructing the Holocene depositional environments in the western part of ancient Karnak temples complex (Egypt): a geoarchaeological approach. Journal of Archaeological Science 38(12), 3204-3216 (2011). DOI: 10.1016/j.jas.2011.06.007 
56. Stewart, M.M.; Larocque-Tobler, I.; Grosjean, M.: Quantitative inter-annual and decadal June-July-August temperature variability ca. 570 BC to AD 120 (Iron Age-Roman Period) reconstructed from the varved sediments of Lake Silvaplana, Switzerland. Journal of Quaternary Science 26(5), 491-501 (2011). DOI: 10.1002/jqs.1480

57. Buentgen, U.; Tegel, W.; Nicolussi, K.; McCormick, M.; Frank, D.; Trouet, V.; Kaplan, J.O.; Herzig, F.; Heussner, K.U.; Wanner, H.; Luterbacher, J.; Esper, J.: 2500 years of European climate variability and human susceptibility. Science 331(6017), 578-582 (2011). DOI: 10.1126/science.1197175

58. Moschen, R.; Kuehl, N.; Peters, S.; Vos, H.; Luecke, A.: Temperature variability at Durres Maar, Germany during the Migration Period and at high medieval times, inferred from stable carbon isotopes of Sphagnum cellulose. Climate of the Past 7(3), 1011-1026 (2011). DOI: 10.5194/cp-7-1011-2011

59. Andric, M.; Jaecks Vidic, N.; Ogrin, M.; Horvat, J.: Palaeoecological evidence for human impact at the forest line at Klek in the Julian Alps. Arheoloski Vestnik 62, 375-392 (2011).

60. Nieto-Moreno, V.; Martinez-Ruiz, F.; Giralt, S.; Jimenez-Espejo, F.J.; Gallego-Torres, D.; Rodrigo-Gamiz, M.; Garcia-Orellana, J.; Ortega-Huertas, M.; de Lange, G.J.: Tracking climate variability in the western Mediterranean during the late Holocene: a multiproxy approach. Climate of the Past 7(4), 1395-1414 (2001). DOI: 10.5194/cp-7-1395-2011

61. Martin-Puertas, C.; Jimenez-Espejo, F.J.; Martinez-Ruiz, F.; Nieto-Moreno, V.; Rodrigo, M.; Mata, M.P.; Valero-Garces, B.L.: Late Holocene climate variability in the southwestern Mediterranean region: an integrated marine and terrestrial geochemical approach. Climate of the Past 6(6), 807-816 (2010). DOI: $10.5194 /$ cp-6-807-2010

62. Ljungqvist, F.C.: A new reconstruction of temperature variability in the extra-tropical northern hemisphere during the last two millennia. Geografiska Annaler Series A - Physical Geography 92A(3), 339-351 (2010). DOI: 10.1111/j.1468-0459.2010.00399.x

63. Martin-Puertas, C.; Valero-Garces, B.L.; Brauer, A.; Mata, M.P.; Delgado-Huertas, A.; Dulski, P.: The Iberian-Roman Humid Period (2600-1600 cal yr BP) in the Zonar Lake varve record (Andalucia, southern Spain). Quaternary Research 71(2), 108-120 (2009). DOI: 10.1016/j.yqres.2008.10.004

64. Thommen, L.: An environmental history of ancient Greece and Rome. Series: (Key themes in ancient history). Cambridge University Press, Cambridge (UK), New York (USA), 200 p. (2012). ISBN: 978-1-107-00216-6 (Hardback) - ISBN: 978-0-521-17465-7 (Paperback). Originally published 2009 in German by Verlag C.H. Beck, Munich (Germany) as "Umweltgeschichte der Antike” by L. Thommen.

65. Orland, I.J.; Bar-Matthews, M.; Kita, N.T.; Ayalon, A.; Matthews, A.; Valley, J.W.: Climate deterioration in the eastern Mediterranean as revealed by ion microprobe analysis of a speleothem that grew from 2.2 to $0.9 \mathrm{ka}$ in Soreq Cave, Israel. Quaternary Research 71(1), 27-35 (2009). DOI: $10.1016 /$ j.yqres.2008.08.005

66. England, A.; Eastwood, W.J.; Roberts, C.N.; Turner, R.; Haldon, J.F.: Historical landscape change in Cappadocia (central Turkey): a palaeoecological investigation of annually laminated sediments from Nar lake. Holocene 18(8), 1229-1245 (2008). DOI: 10.1177/0959683608096598

67. Martin-Puertas, C.; Valero-Garces, B.L.; Mata, M.P.; Gonzalez-Samperiz, P.; Bao, R.; Moreno, A.; Stefanova, V.: Arid and humid phases in southern Spain during the last 4000 years: the Zonar Lake record, Cordoba. Holocene 18(6), 907-921 (2008). DOI: 10.1177/0959683608093533

68. Schmidt, R.; Kamenik, C.; Roth, M.: Siliceous algae-based seasonal temperature inference and indicator pollen tracking ca. 4000 years of climate/land use dependency in the southern Austrian Alps. Journal of Paleolimnology 38(4), 541-554 (2007). DOI: 10.1007/s10933-007-9089-y 
69. Brochier, J.L.; Borel, J.L.; Druart, J.C.: Paleoenvironmental variations from 1000 BC to $1000 \mathrm{AD}$ and late antiquity and medieval climatic optima on northwestern Alps piedmont at Colletitre, Paladru Lake, France. Quaternaire 18(3), 253-270 (2007).

70. Lippi, M.M.; Bellini, C.; Trinci, C.; Benvenuti, M.; Pallecchi, P.; Sagri, M.: Pollen analysis of the ship site of Pisa San Rossore, Tuscany, Italy: the implications for catastrophic hydrological events and climatic change during the late Holocene. Vegetation History and Archaeobotany 16(6), 453-465 (2007). DOI: $10.1007 / \mathrm{s} 00334-006-0070-x$

71. Chapron, E.; Arnaud, F.; Noel, H.; Revel, M.; Desmet, M.; Perdereau, L.: Rhone river flood deposits in Lake Le Bourget: a proxy for Holocene environmental changes in the NW Alps, France. Boreas 34(4), 404-416 (2005). DOI: 10.1080/03009480500231260

72. van der Leeuw, S.E.: Climate, hydrology, land use, and environmental degradation in the lower Rhone Valley during the Roman period. Comptes Rendus Geoscience 337(1-2), 9-27 (2005). DOI: $10.1016 /$ j.crte.2004.10.018

73. Brambati, A.; Quaia, T.: Special issue - Global climate changes during the Late Quaternary - Selected papers of the Accademia Nazionale dei Lincei International Conference, Rome, Italy, 3-4 May 2001 (foreword). Published in: Global and Planetary Change 40(1-2), 1-1 (2004). DOI: 10.1016/S0921-8181(03)00093-6

74. Desprat, S.; Goni, M.F.S.; Loutre, M.F.: Revealing climatic variability of the last three millennia in northwestern Iberia using pollen influx data. Earth and Planetary Science Letters 213(1-2), 63-78 (2003). DOI: 10.1016/S0012-821X(03)00292-9

75. Berglund, B.E.: Human impact and climate changes - synchronous events and a causal link? Quaternary International 105, 7-12, article number: PII S1040-6182(02)00144-1 (2003). DOI: 10.1016/S1040-6182(02)00144-1

76. Mastrolorenzo, G.; Palladino, D.M.; Vecchio, G.; Taddeucci, J.: The 472 AD Pollena eruption of Somma-Vesuvius (Italy) and its environmental impact at the end of the Roman Empire. Journal of Volcanology and Geothermal Research 113(1-2), 19-36, article number: PII S0377-0273(01)00248-7 (2002). DOI: $10.1016 /$ S0377-0273(01)00248-7

77. Knottnerus, O.S.: Malaria around the North Sea: a survey. Edited by: Wefer G.; Berger W.H.; Behre K.E.; Jansen E.: Climate development and history of the North-Atlantic realm, 339-353 (2002). 1st Hanse conference on past climate and its significance for human history in northwestern Europe. October 09-14 1999, Delmenhorst (Germany).

78. McDermott, F.; Mattey, D.P.; Hawkesworth, C.: Centennial-scale Holocene climate variability revealed by a high-resolution speleothem delta O-18 record from SW Ireland. Science 294(5545), 1328-1331 (2001). DOI: 10.1126/science.1063678

79. Reale, O.; Dirmeyer, P.: Modeling the effects of vegetation on Mediterranean climate during the Roman Classical Period. Part I: Climate history and model sensitivity. Global and Planetary Change 25(3-4), 163-184 (2000). DOI: 10.1016/S0921-8181(00)00002-3

80. Reale, O.; Shukla, J.: Modeling the effects of vegetation on Mediterranean climate during the Roman Classical Period: Part II. Model simulation. Global and Planetary Change 25(3-4), 185-214 (2000). DOI: 10.1016/S0921-8181(00)00003-5

81. Dumayne-Peaty, L.: Continuity or discontinuity? Vegetation change in the Hadrianic-Antonine frontier zone of northern Britain at the end of the Roman occupation. Journal of Biogeography 26(3), 643-665 (1999). DOI: 10.1046/j.1365-2699.1999.00295.x 
82. Brown, N.: Climate change and human history - some indications from Europe, AD 400-1400. Environmental Pollution 83(1-2), 37-43 (1994). DOI: 10.1016/0269-7491(94)90020-5

83. Camuffo, D.: Reconstructing the climate and the air-pollution of Rome during the life of the Trajan column. Science of the Total Environment 128(2-3), 205-226 (1993). DOI: 10.1016/0048-9697(93)90220-Z

84. Murphey, R.: The decline of North Africa since the Roman occupation: climatic or human? Annals of the Association of American geographers 41(2), 116-132 (1951).

85. Huntington, E.: Climatic change and agricultural exhaustion as elements in the fall of Rome. Quarterly Journal of Economics 31(2), 173-208 (1917). DOI: 10.2307/1883908

The cited papers $(n=49)$ are marked with an asterisk in the reference list below.

\section{References}

1. Drake, B.L. Changes in North Atlantic Oscillation drove population migrations and the collapse of the Western Roman Empire. Sci. Rep. 2017, 7, 1227. [CrossRef] [PubMed]

2. Demandt, A. Der Fall Roms: Die Auflösung des Römischen Reiches im Urteil der Nachwelt, 1st ed.; Verlag C.H. Beck: Munich, Germany, 1984; 695p, ISBN-10 3406095984, ISBN-13 978-3406095986.

3. Demandt, A. Geschichte der Spätantike: Das Römische Reich von Diocletian bis Justinian 284-565 n. Chr., 2nd ed.; Verlag C.H. Beck: Munich, Germany, 2008; 604p, ISBN-10 3406572413, ISBN-13 978-3406572418.

4. Harper, K. Climate change and the course of global history: A rough journey. J. Interdiscip. Hist. 2015, 45, 549-566. [CrossRef]

5. Bornmann, L.; Marx, W. The Anna Karenina principle: A way of thinking about success in science. J. Am. Soc. Inf. Sci. Technol. 2012, 63, 2037-2051. [CrossRef]

6. Brown, P. The World of Late Antiquity: From Marcus Aurelius to Muhammad, 1st ed.; Thames and Hudson: New York, NY, USA, 1971; 216p, ISBN-10 0500330220, ISBN-13 9780500330227.

7. Heather, P. The Fall of the Roman Empire: A New History of Rome and the Barbarians, 1st ed.; Oxford University Press: Oxford, UK, 2005; 608p, ISBN-10 0195159543, ISBN-13 978-0195159547.

8. Ward-Perkins, B. The Fall of Rome: And the End of Civilization, 1st ed.; Oxford University Press: Oxford, UK, 2005; 248p, ISBN-10 0192805649, ISBN-13 978-0192805645.

9. Interview Ward-Perkins. 2006. Available online: http:/ /www.bu.edu/historic/hs/perkins.pdf (accessed on 7 June 2018).

10. Brooke, J.L. Climate Change and the Course of Global History: A Rough Journey, 1st ed.; Cambridge University Press: New York, NY, USA, 2014; 654p, ISBN-10 0521871646, ISBN-13 978-0521871648.

11. Gibbon, E. The History of the Decline and Fall of the Roman Empire, 1st ed.; Printed for W. Strahan and T. Cadell; Strand: London, UK; Volume I-VI, pp. 1776-1788.

12. Huntington, E. Climatic change and agricultural exhaustion as elements in the fall of Rome. Q. J. Econ. 1917, 31, 173-208. [CrossRef]

13. Harper, K. Fate of Rome: Climate, Disease, and the End of an Empire, 1st ed.; Princeton University Press, The Princeton History of the Ancient World: Princeton, NJ, USA, 2017; 417p, ISBN-10 0691166838, ISBN-13 978-0691166834.

14. Marx, W.; Haunschild, R.; Bornmann, L. The Role of climate in the collapse of the Maya civilization: A bibliometric analysis of the scientific discourse. Climate 2017, 5, 88. [CrossRef]

15. Buckland, M.; Gey, F. The relationship between recall and precision. J. Am. Soc. Inf. Sci. 1994, 45, 12-19. [CrossRef]

16. Moravcsik, A. The fate of Rome: Climate, disease, and the end of an empire. Foreign Aff. 2018, 97, 160.

17. Decker, M.J. Approaches to the environmental history of Late Antiquity, part II: Climate change and the end of the Roman Empire. Hist. Compass 2017, 15, e12425. [CrossRef]

18. Storey, R.; Storey, G.R. Rome and the Classic Maya: Comparing the low Collapse of Civilizations, 1st ed.; Routledge: Oxford, UK, 2017; 280p, ISBN 978-1-62958-458-4 (pbk), ISBN 978-1-315-30941-5 (ebk), ISBN 978-1-62958-457-7 (hbk).

19. Harper, K. The environmental fall of the Roman Empire. Daedalus 2016, 145, 101-111. [CrossRef] 
20. Izdebski, A.; Pickett, J.; Roberts, N.; Waliszewski, T. The environmental, archaeological and historical evidence for regional climatic changes and their societal impacts in the Eastern Mediterranean in Late Antiquity. Quat. Sci. Rev. 2016, 136, 189-208. [CrossRef]

21. McCormick, M.; Buentgen, U.; Cane, M.A.; Cook, E.R.; Harper, K.; Huybers, P.; Litt, T.; Manning, S.W.; Mayewski, P.A.; More, A.F.M.; et al. Climate change during and after the Roman Empire: Reconstructing the past from scientific and historical evidence. J. Interdiscip. Hist. 2012, 43, 169-220. [CrossRef]

22. Buentgen, U.; Tegel, W.; Nicolussi, K.; McCormick, M.; Frank, D.; Trouet, V.; Kaplan, J.O.; Herzig, F.; Heussner, K.U.; Wanner, H.; et al. 2500 years of European climate variability and human susceptibility. Science 2011, 331, 578-582. [CrossRef] [PubMed]

23. Brown, N. Climate change and human history-Some indicators from Europe, AD 400-1400. Environ. Pollut. 1994, 83, 37-43. [CrossRef]

24. Haunschild, R.; Bornmann, L.; Marx, W. Climate change research in view of bibliometrics. PLoS ONE 2016, 11, e0160393. [CrossRef] [PubMed]

25. Wacholder, N. Interactive query formulation. Ann. Rev. Inf. Sci. Technol. 2011, 45, 157-196. [CrossRef]

26. Oumghar, S. The climate of North Africa in the Roman era: New approaches. Hesperis-Tamuda 2017, 52, $49-81$.

27. VOSviewer-Visualizing Scientific Landscapes. Available online: http:/ / www.vosviewer.com (accessed on 7 June 2018).

28. Waltman, L.; van Eck, N.J.; Noyons, E.C.M. A unified approach to mapping and clustering of bibliometric networks. J. Informetr. 2010, 4, 629-635. [CrossRef]

29. CitNetExplorer-Analyzing Citation Patterns in Scientific Literature. Available online: http://www. citnetexplorer.nl (accessed on 7 June 2018).

30. Van Eck, N.J.; Waltman, L. CitNetExplorer: A new software tool for analyzing and visualizing citation networks. J. Informetr. 2014, 8, 802-823. [CrossRef]

31. Altmetric-Who's Talking about Your Research? Available online: https://www.altmetric.com (accessed on 7 June 2018).

32. Luterbacher, J.; Werner, J.P.; Smerdon, J.E.; Fernandez-Donado, L.; Gonzalez-Rouco, F.J.; Barriopedro, D.; Ljungqvist, F.C.; Buentgen, U.; Zorita, E.; Wagner, S.; et al. European summer temperatures since Roman times. Environ. Res. Lett. 2016, 11, 024001. [CrossRef]

33. Sapart, C.J.; Monteil, G.; Prokopiou, M.; van de Wal, R.S.W.; Kaplan, J.O.; Sperlich, P.; Krumhardt, K.M.; van der Veen, C.; Houweling, S.; Krol, M.C.; et al. Natural and anthropogenic variations in methane sources during the past two millennia. Nature 2012, 490, 85-88. [CrossRef] [PubMed]

34. Izdebski, A.; Holmgren, K.; Weiberg, E.; Stocker, S.R.; Buentgen, U.; Florenzano, A.; Gogou, A.; Leroy, S.A.G.; Luterbacher, J.; Martrat, B.; et al. Realising consilience: How better communication between archaeologists, historians and natural scientists can transform the study of past climate change in the Mediterranean. Quat. Sci. Rev. 2016, 136, 5-22. [CrossRef]

35. Helama, S.; Arppe, L.; Uusitalo, J.; Holopainen, J.; Makela, H.M.; Makinen, H.; Mielikainen, K.; Nojd, P.; Sutinen, R.; Taavitsainen, J.P.; et al. Volcanic dust veils from sixth century tree-ring isotopes linked to reduced irradiance, primary production and human health. Sci. Rep. 2018, 8, 1339. [CrossRef] [PubMed]

36. Masi, A.; Francke, A.; Pepe, C.; Thienemann, M.; Wagner, B.; Sadori, L. Vegetation history and paleoclimate at Lake Dojran (FYROM/Greece) during the Late Glacial and Holocene. Clim. Past 2018, 14, 351-367. [CrossRef]

37. Morellon, M.; Anselmetti, F.S.; Ariztegui, D.; Brushulli, B.; Sinopoli, G.; Wagner, B.; Sadori, L.; Gilli, A.; Pambuku, A. Human-climate interactions in the Central Mediterranean region during the last millennia: The laminated record of Lake Butrint (Albania). Quat. Sci. Rev. 2016, 136, 134-152. [CrossRef]

38. Cisneros, M.; Cacho, I.; Frigola, J.; Canals, M.; Masque, P.; Martrat, B.; Casado, M.; Grimalt, J.O.; Pena, L.D.; Margaritelli, G.; et al. Sea surface temperature variability in the central-western Mediterranean Sea during the last 2700 years: A multi-proxy and multi-record approach. Clim. Past 2016, 12, 849-869. [CrossRef]

39. Sanchez-Lopez, G.; Hernandez, A.; Pla-Rabes, S.; Trigo, R.M.; Toro, M.; Granados, I.; Saez, A.; Masque, P.; Pueyo, J.J.; Rubio-Ingles, M.J.; et al. Climate reconstruction for the last two millennia in Central Iberia: The role of East Atlantic (EA), North Atlantic Oscillation (NAO) and their interplay over the Iberian Peninsula. Quat. Sci. Rev. 2016, 149, 135-150. [CrossRef] 
40. Nieto-Moreno, V.; Martinez-Ruiz, F.; Giralt, S.; Jimenez-Espejo, F.J.; Gallego-Torres, D.; Rodrigo-Gamiz, M.; Garcia-Orellana, J.; Ortega-Huertas, M.; de Lange, G.J. Tracking climate variability in the Western Mediterranean during the Late Holocene: A multiproxy approach. Clim. Past 2011, 7, 1395-1414. [CrossRef]

41. Martin-Puertas, C.; Valero-Garces, B.L.; Mata, M.P.; Gonzalez-Samperiz, P.; Bao, R.; Moreno, A.; Stefanova, V. Arid and humid phases in Southern Spain during the last 4000 years: The Zonar Lake record, Cordoba. Holocene 2008, 18, 907-921. [CrossRef]

42. Martin-Puertas, C.; Valero-Garces, B.L.; Brauer, A.; Mata, M.P.; Delgado-Huertas, A.; Dulski, P. The Iberian-Roman Humid Period (2600-1600 cal yr BP) in the Zonar Lake varve record (Andalucia, Southern Spain). Quat. Res. 2009, 71, 108-120. [CrossRef]

43. Martin-Puertas, C.; Jimenez-Espejo, F.J.; Martinez-Ruiz, F.; Nieto-Moreno, V.; Rodrigo, M.; Mata, M.P.; Valero-Garces, B.L. Late Holocene climate variability in the Southwestern Mediterranean region: An integrated marine and terrestrial geochemical approach. Clim. Past 2010, 6, 807-816. [CrossRef]

44. Esper, J.; Duthorn, E.; Krusic, P.J.; Timonen, M.; Buentgen, U. Northern European summer temperature variations over the Common Era from integrated tree-ring density records. J. Quat. Sci. 2014, 29, 487-494. [CrossRef]

45. Ljungqvist, F.C. A new reconstruction of temperature variability in the extra-tropical Northern Hemisphere during the last two millennia. Geogr. Ann. Ser. A Phys. Geogr. 2010, 92A, 339-351. [CrossRef]

46. Marx, W.; Bornmann, L. The emergence of plate tectonics and the Kuhnian model of paradigm shift: A bibliometric case study based on the Anna Karenina principle. Scientometrics 2013, 94, 595-614. [CrossRef]

47. Murphey, R. The decline of North Africa since the Roman occupation: Climatic or human? Ann. Assoc. Am. Geogr. 1951, 116-132. [CrossRef]

48. McDermott, F.; Mattey, D.P.; Hawkesworth, C. Centennial-scale Holocene climate variability revealed by a high-resolution speleothem delta O-18 record from SW Ireland. Science 2001, 294, 1328-1331. [CrossRef] [PubMed]

49. Mensing, S.A.; Tunno, I.; Sagnotti, L.; Florindo, F.; Noble, P.; Archer, C.; Zimmerman, S.; Pavon-Carrasco, F.J.; Cifani, G.; Passigli, S.; et al. 2700 years of Mediterranean environmental change in Central Italy: A synthesis of sedimentary and cultural records to interpret past impacts of climate on society. Quat. Sci. Rev. 2015, 116, 72-94. [CrossRef]

50. Desprat, S.; Goni, M.F.S.; Loutre, M.F. Revealing climatic variability of the last three millennia in Northwestern Iberia using pollen influx data. Earth Planet. Sci. Lett. 2003, 213, 63-78. [CrossRef]

51. Curras, A.; Zamora, L.; Reed, J.M.; Garcia-Soto, E.; Ferrero, S.; Armengol, X.; Mezquita-Joanes, F.; Marques, M.A.; Riera, S.; Julia, R. Climate change and human impact in Central Spain during Roman times: High-resolution multi-proxy analysis of a tufa lake record (Somolinos, $1280 \mathrm{~m}$ asl). Catena 2012, 89, 31-53. [CrossRef]

52. Schmidt, R.; Kamenik, C.; Roth, M. Siliceous algae-based seasonal temperature inference and indicator pollen tracking ca. 4000 years of climate/land use dependency in the Southern Austrian Alps. J. Paleolimnol. 2007, 38, 541-554. [CrossRef]

53. Rudzka, D.; Mcdermott, F.; Suric, M. A late Holocene climate record in stalagmites from Modric Cave (Croatia). J. Quat. Sci. 2012, 27, 585-596. [CrossRef]

54. Psomiadis, D.; Dotsika, E.; Albanakis, K.; Ghaleb, B.; Hillaire-Marcel, C. Speleothem record of climatic changes in the Northern Aegean region (Greece) from the Bronze Age to the collapse of the Roman Empire. Palaeogeogr. Palaeoclimatol. Palaeoecol. 2018, 489, 272-283. [CrossRef]

55. Fuks, D.; Ackermann, O.; Ayalon, A.; Bar-Matthews, M.; Bar-Oz, G.; Levi, Y.; Maeir, A.M.; Weiss, E.; Zilberman, T.; Safrai, Z. Dust clouds, climate change and coins: Consiliences of palaeoclimate and economy in the Late Antique Southern Levant. Levant 2017, 49, 205-223. [CrossRef]

56. Bar-Matthews, M.; Ayalon, A. Mid-Holocene climate variations revealed by high-resolution speleothem records from Soreq Cave, Israel and their correlation with cultural changes. Holocene 2011, 21, 163-171. [CrossRef]

57. Bar-Matthews, M.; Ayalon, A.; Kaufman, A.; Wasserburg, G.J. The Eastern Mediterranean paleoclimate as a reflection of regional events: Soreq cave, Israel. Earth Planet. Sci. Lett. 1999, 166, 85-95. [CrossRef]

58. Orland, I.J.; Bar-Matthews, M.; Kita, N.T.; Ayalon, A.; Matthews, A.; Valley, J.W. Climate deterioration in the Eastern Mediterranean as revealed by ion microprobe analysis of a speleothem that grew from 2.2 to $0.9 \mathrm{ka}$ in Soreq Cave, Israel. Quat. Res. 2009, 71, 27-35. [CrossRef] 
59. Ghilardi, M.; Boraik, M. Reconstructing the Holocene depositional environments in the western part of Ancient Karnak temples complex (Egypt): A geoarchaeological approach. J. Archaeol. Sci. 2011, 38, 3204-3216. [CrossRef]

60. Grauel, A.L.; Goudeau, M.L.S.; de Lange, G.J.; Bernasconi, S.M. Climate of the past 2500 years in the Gulf of Taranto, Central Mediterranean Sea: A high-resolution climate reconstruction based on delta O-18 and delta C-13 of Globigerinoides ruber (white). Holocene 2013, 23, 1440-1446. [CrossRef]

61. Bakker, J.; Paulissen, E.; Kaniewski, D.; Poblome, J.; De Laet, V.; Verstraeten, G.; Waelkens, M. Climate, people, fire and vegetation: New insights into vegetation dynamics in the Eastern Mediterranean since the 1st century AD. Clim. Past 2013, 9, 57-87. [CrossRef]

62. Moschen, R.; Kuehl, N.; Peters, S.; Vos, H.; Luecke, A. Temperature variability at Durres Maar, Germany during the Migration Period and at High Medieval Times, inferred from stable carbon isotopes of Sphagnum cellulose. Clim. Past 2011, 7, 1011-1026. [CrossRef]

63. Franke, J.G.; Donner, R.V. Dynamical anomalies in terrestrial proxies of North Atlantic climate variability during the last $2 \mathrm{ka}$. Clim. Chang. 2017, 143, 87-100. [CrossRef]

64. Reale, O.; Dirmeyer, P. Modeling the effects of vegetation on Mediterranean climate during the Roman Classical Period. Part I: Climate history and model sensitivity. Glob. Planet. Chang. 2000, 25, 163-184. [CrossRef]

65. Reale, O.; Shukla, J. Modeling the effects of vegetation on Mediterranean climate during the Roman Classical Period. Part II: Model simulation. Glob. Planet. Chang. 2000, 25, 185-214. [CrossRef]

66. Manning, S.W. The Roman World and Climate: Context, Relevance of Climate Change, and some Issues. In The Ancient Mediterranean Environment between Science and History, 1st ed.; Harris, W.V., Ed.; Columbia Studies in the Classical Tradition; Brill: Leiden, The Netherlands; Boston, MA, USA, 2013; Volume 39, pp. 103-170. 334p, ISBN-10 9004253432, ISBN-13 978-9004253438.

67. Brambati, A.; Quaia, T. Special issue-Global climate changes during the Late Quaternary-Selected papers of the Accademia Nazionale dei Lincei International Conference, Rome, Italy, 3-4 May 2001. Foreword. Glob. Planet. Chang. 2004, 40, 1. [CrossRef]

68. Elliott, C.P. The Antonine Plague, climate change and local violence in Roman Egypt. Past Present 2016, 231, 3-31. [CrossRef]

69. Mastrolorenzo, G.; Palladino, D.M.; Vecchio, G.; Taddeucci, J. The 472 AD Pollena eruption of Somma-Vesuvius (Italy) and its environmental impact at the end of the Roman Empire. J. Volcanol. Geotherm. Res. 2002, 113, 19-36. [CrossRef]

70. Passchier, C.; Surmelihindi, G.; Spoetl, C.; Mertz-Kraus, R.; Scholz, D. Carbonate deposits from the ancient aqueduct of Beziers, France-A high-resolution palaeoenvironmental archive for the Roman Empire. Palaeogeogr. Palaeoclimatol. Palaeoecol. 2016, 461, 328-340. [CrossRef]

71. Passchier, C.; Surmelihindi, G.; Spoetl, C. A high-resolution palaeoenvironmental record from carbonate deposits in the Roman aqueduct of Patara, SW Turkey, from the time of Nero. Sci. Rep. 2016, 6, 28704. [CrossRef] [PubMed]

72. Gilly, J.C.; Plegat, R.; Coudray, J. Preliminary note on calcium incrustations of Roman aqueduct of Pont-Du-Gard, paleoclimatic and paleochronological indicators of first 5 years of present area. C. R. Hebd. Seances Acad. Sci. 1971, 273, 1668-1670.

73. Cook, E.R. Megadroughts, ENSO, and the Invasion of Late-Roman Europe by the Huns and Avars. In The Ancient Mediterranean Environment between Science and History, Columbia Studies in the Classical Tradition; Harris, W.V., Ed.; Brill: Leiden, The Netherlands, 2013; Volume 39, pp. 89-102. ISBN 978-90-04-25405-3. [CrossRef]

74. Sheppard, P.R.; Tarasov, P.E.; Graumlich, L.J.; Heussner, K.U.; Wagner, M.; Osterle, H.; Thompson, L.G. Annual precipitation since $515 \mathrm{BC}$ reconstructed from living and fossil juniper growth of northeastern Qinghai Province, China. Clim. Dyn. 2004, 23, 869-881. [CrossRef]

75. Zhang, Q.B. A millennium-long tree-ring chronology of Sabina przewalskii on Northeastern Qinghai-Tibetan Plateau. Dendrochronologia 2007, 24, 91-95. [CrossRef]

76. Bokovenko, N.A. Migrations of early nomads of the Eurasian steppe in a context of climate changes. In NATO Science Series IV. Earth and Environmental Sciences, Vol. 42: Impact of Environment on Human Migration in Eurasia; Scott, E.M., Yu, A., Zaitseva, A., Zaitseva, G., Eds.; Kluwer Academic Publishers: Dordrecht, The Netherlands, 2004; pp. 21-33. 
77. Saunders, J.J. The debate on the Fall of Rome. History 1963, 48, 1-17. [CrossRef]

78. Nichols, J. Mapping the Crisis of the Third Century. In Impact of Empire, Volume 7: Crises and the Roman Empire: Proceedings of the Seventh Workshop of the International Network Impact of Empire, Nijmegen, The Netherlands, 20-24 June 2007; Hekster, O., de Kleijn, G., Slootjes, D., Eds.; Brill Academic Publishers: Boston, MA, USA, 2007; pp. 431-437.

79. Di Cosmo, N.; Oppenheimer, C.; Buntgen, U. Interplay of environmental and socio-political factors in the downfall of the Eastern Turk Empire in 630 CE. Clim. Chang. 2017, 145, 383-395. [CrossRef]

80. Di Cosmo, N.; Hessl, A.; Leland, C.; Byambasuren, O.; Tian, H.Q.; Nachin, B.; Pederson, N.; Andreu-Hayles, L.; Cook, E.R. Environmental stress and steppe nomads: Rethinking the history of the Uyghur Empire (744-840) with paleoclimate data. J. Interdiscip. Hist. 2018, 48, 439-463. [CrossRef]

81. Buentgen, U.; Myglan, V.S.; Ljungqvist, F.C.; McCormick, M.; Di Cosmo, N.; Sigl, M.; Jungclaus, J.; Wagner, S.; Krusic, P.J.; Esper, J.; et al. Cooling and societal change during the Late Antique Little Ice Age from 536 to around 660 AD. Nat. Geosci. 2016, 9, 231-237. [CrossRef]

82. Fagan, B. The Great Warming: Climate Change and the Rise and Fall of Civilizations, 1st ed.; Bloomsbury Press: New York, NY, USA, 2008; 282p, ISBN-10 1596913924, ISBN-13 978-1596913929.

83. Diamond, J. Collapse: How Societies Choose to Fail or Succeed, 1st ed.; Viking Adult, Penguin Group: New York, NY, USA; Toronto, ON, Canada; London, UK, 2004; 592p, ISBN-10 0670033375, ISBN-13 978-0670033379.

84. Weiss, H.; Bradley, R.S. What drives societal collapse? Science 2001, 291, 609-610. [CrossRef] [PubMed]

85. Haldon, J. The Empire That Would Not Die: The Paradox of Eastern Roman Survival; Harvard University Press: Cambridge, MA, USA, 2016; pp. 640-740. 432p, ISBN-10 0674088778, ISBN-13 978-0674088771.

86. Haldon, J.; Mordechai, L.; Newfield, T.P.; Chase, A.F.; Izdebski, A.; Guzowski, P.; Labuhn, I.; Roberts, N. History meets palaeoscience: Consilience and collaboration in studying past societal responses to environmental change. Proc. Natl. Acad. Sci. USA 2018, 115, 3210-3218. [CrossRef] [PubMed]

(C) 2018 by the authors. Licensee MDPI, Basel, Switzerland. This article is an open access article distributed under the terms and conditions of the Creative Commons Attribution (CC BY) license (http:// creativecommons.org/licenses/by/4.0/). 